\title{
Thermochemical Performance Assessment of Solar Continuous \\ Methane-Driven ZnO Reduction for Co-Production of Pure Zinc and Hydrogen-Rich Syngas
}

\section{Srirat Chuayboon ${ }^{a}$, Stéphane Abanades ${ }^{\text {b,* }}$}

\footnotetext{
${ }^{a}$ Department of Mechanical Engineering, King Mongkut's Institute of Technology Ladkrabang, Prince of Chumphon Campus, Chumphon 86160, Thailand

${ }^{\mathrm{b}}$ Processes, Materials and Solar Energy Laboratory, PROMES-CNRS, 7 Rue du Four Solaire, 66120 FontRomeu, France
}

*Corresponding author: Tel +33 (0)4 68307730

E-mail address: stephane.abanades@promes.cnrs.fr

Declarations of interest: none

\begin{abstract}
Converting renewable solar energy to dispatchable chemical products via solar-driven thermochemical processes is one of the best solutions for long-term solar energy storage and renewable fuel production. This study addresses the performance assessment of continuous
\end{abstract}


methane-driven $\mathrm{ZnO}$ reduction, fully powered by renewable solar heat, for co-production of hydrogen-rich syngas and metallic $\mathrm{Zn}$ in a solar prototype consuming-bed chemical reactor. On-sun experiments were conducted under continuous $\mathrm{ZnO}$ and $\mathrm{CH}_{4}$ co-feeding to assess the effect of key parameters (inlet $\mathrm{CH}_{4} / \mathrm{ZnO}$ molar ratio: $1-1.5$, temperature: $900-1000{ }^{\circ} \mathrm{C}$, and $\mathrm{ZnO}$ feeding rate: $0.5-1.5 \mathrm{~g} / \mathrm{min}$ ) in order to maximize syngas and $\mathrm{Zn}$ yields, and reactor performance metrics. As a result, a rise in either the $\mathrm{CH}_{4} / \mathrm{ZnO}$ molar ratio or temperature enhanced the reaction extent but favored solid carbon formation, which downgraded syngas products quality, and consumed more solar energy input. Increasing $\mathrm{ZnO}$ feeding rate under a constant $\mathrm{ZnO} / \mathrm{CH}_{4}$ molar ratio significantly promoted $\mathrm{ZnO}+\mathrm{CH}_{4}$ reaction performance thanks to both hastened $\mathrm{ZnO}$ consumption rate (boosting products yield) and reduced solar energy consumption (improving solar conversion efficiency). However, excessively high $\mathrm{ZnO}$ feeding rate caused temporal $\mathrm{ZnO}$ accumulation in the reactor. Optimal operating conditions for on-sun continuous methane-driven $\mathrm{ZnO}$ reduction were identified (at $\mathrm{ZnO}$ feeding rate $=1.2 \mathrm{~g} / \mathrm{min}, \mathrm{CH}_{4} / \mathrm{ZnO}$ molar ratio $=1.5$, and temperature $=950{ }^{\circ} \mathrm{C}$ ), yielding total syngas yield of $12.3 \mathrm{mmol} / \mathrm{g}_{\mathrm{ZnO}}$, solid carbon formation down to $0.58 \mathrm{mmol} / \mathrm{g}_{\mathrm{ZnO}}, \mathrm{ZnO}$ conversion of $63.0 \%$, methane conversion of $10.6 \%$, energy upgrade factor of 1.08 , and solar-to-fuel energy conversion efficiency of 5.3\%. High-purity $\mathrm{Zn}$ particles with hexagonal morphologies were generated in continuous mode, demonstrating the proposed approach feasibility and reliability for simultaneous methane conversion to syngas and metallic $\mathrm{Zn}$ production in a single process.

Keywords: Concentrated sunlight, Solar reactor, Methane reforming, Metallurgy, Oxygen carrier, Synthesis gas. 


\section{Introduction}

Getting full benefit of the plentiful renewable solar energy is an achievable objective to deal with the growing global energy demand and alleviate global warming caused by fossil fuels combustion [1]. Challenging issues lie in how to harvest the relatively diffuse, dilute, and intermittent solar energy [2].

Solar-driven thermochemical processes are promising pathways to efficiently convert sunlight into chemical energy including synthesis gas $\left(\mathrm{H}_{2}\right.$ and $\left.\mathrm{CO}\right)$ and metal products [3]. Syngas can be further converted to various hydrocarbons such as methanol or other dispatchable liquid fuels. The solar-driven thermochemical conversion processes consist of gasification [4], chemical-looping gasification [5], carbothermal reduction [6], $\mathrm{H}_{2} \mathrm{O} / \mathrm{CO}_{2}$ splitting [7], and chemical-looping methane reforming [8].

One promising process is solar methane-driven reduction of metal oxides (MOs) [9-11]. MOs can serve as both the solid oxidizing agent for methane reforming (oxygen carrier material) and as the feedstock for the metallurgical process while methane acts as the reducing agent. The reaction thus consists of partial oxidation of methane to produce syngas and simultaneous MOs reduction to produce metals. This endothermic reaction delivers both syngas and metals in a single reaction with solar energy storage into products.

The selection of proper MOs is one of the crucial points of this system. Several MOs have been considered involving non-volatile oxides (such as ceria [12], iron oxides [13], and perovskites [14,15]) and volatile oxides (such as $\mathrm{MgO}$ [16], $\mathrm{SnO}_{2}$ [17], and $\mathrm{ZnO}$ [18-20]).

Non-volatile MOs remain in solid-state over the process while exchanging oxygen, thus avoiding a metal recombination issue. Their selection relies on their lattice oxygen capacity for syngas production. Otsuka et al. [21,22] proposed pure ceria for partial oxidation of methane and showed both possible methane-to-syngas conversion (with an ideal $\mathrm{H}_{2}: \mathrm{CO}$ ratio 
of 2:1) and reduced ceria re-oxidation with $\mathrm{CO}_{2}$. However, pure ceria showed low reduction capacity, which resulted in low $\mathrm{CO} / \mathrm{H}_{2}$ yield. Then, $\mathrm{CeO}_{2}$-based oxides were applied to improve lattice oxygen capacity [23].

To enhance the syngas yield, volatile MOs are utilized in partial oxidation of methane $[13,24,25]$. Despite possible product recombination that can be alleviated by quenching, $\mathrm{ZnO}$ has been of particular interest in partial oxidation of methane for simultaneous co-production of syngas and metallic $\mathrm{Zn}[26,27]$. Besides, $\mathrm{Zn}$ is an important material for various key applications such as electric batteries and corrosion-resistant zinc plating of iron [28] and can be also an oxygen carrier in solar-driven $\mathrm{H}_{2} \mathrm{O} / \mathrm{CO}_{2}$ splitting systems [29].

Although solar-driven direct $\mathrm{ZnO}$ thermal dissociation $\left(\mathrm{ZnO} \rightarrow \mathrm{Zn}+1 / 2 \mathrm{O}_{2}\right)$ was proved to be possible, its high reduction temperature (exceeding $1800{ }^{\circ} \mathrm{C}$ at atmospheric pressure) and possible $\mathrm{Zn}$ recombination represent major challenges [30-33].

Importantly, different studies demonstrated that $\mathrm{ZnO}$ reduction temperature can be substantially decreased to $900{ }^{\circ} \mathrm{C}$ [34] by reacting with solid carbon [35-37], carbonaceous materials such as biomass [5], or gaseous methane [36,38,39].

The global reaction of solar-driven partial oxidation of methane combined with $\mathrm{ZnO}$ reduction (namely, methane-driven $\mathrm{ZnO}$ reduction) can be represented by Eq. 1 .

$$
\mathrm{ZnO}+\mathrm{CH}_{4}+\text { solar heat } \rightarrow \mathrm{Zn}+2 \mathrm{H}_{2}+\mathrm{CO} \quad\left(\Delta \mathrm{H}^{\circ}=444.96 \mathrm{~kJ} / \mathrm{mol}, \mathrm{T}_{\left(@ \Delta \mathrm{G}^{\circ}=0\right)}=840^{\circ} \mathrm{C}\right)
$$

This process is an alternative to conventional methane reforming and provides various advantages since it uses a solid oxidant. It produces a pure metal as a chemical commodity that can be valorized, while process heat can be supplied by concentrated solar energy as the only high-temperature heat source. Metallic $\mathrm{Zn}$ vapor is produced at the reaction temperature (Zn boiling point $=907{ }^{\circ} \mathrm{C}$ ) along with hydrogen-rich syngas with an ideal $\mathrm{H}_{2} / \mathrm{CO}$ ratio of 
two, suitable for syngas conversion to methanol. In contrast, conventional methane reforming yields $\mathrm{H}_{2} / \mathrm{CO}$ ratio of three for steam reforming and one for dry reforming. Moreover, the conventional process entails several drawbacks. Process heat is generally supplied by the combustion of additional methane/natural gas feedstock (around 3-20\% of the total feedstock consumption of the plant [40]), resulting in additional feedstock consumption and associated greenhouse gas emissions. Catalysts such as nickel are also necessary, possibly resulting in deactivation and additional cost issues associated with the regeneration/periodic replacement of catalysts. Furthermore, conventional steam reforming requires excess superheat steam to prevent carbon deposition, thus inducing sensible heating penalties. Besides, conventional dry reforming exhibits product recombination, and produced $\mathrm{CO}: \mathrm{H}_{2}$ ratio needs to be adjusted properly via the water-gas shift reaction for Fischer-Tropsch synthesis, while the excess $\mathrm{CO}_{2}$ needs to be removed by pressure swing adsorption for final purification [41]. Using a solid oxidizer in solar methane reforming is therefore advantageous as it eliminates the need for a catalyst, while the solid particles can act as efficient solar radiation absorbers directly to the reaction site. For these reasons, solar-driven methane reforming with solid $\mathrm{ZnO}$ for both syngas and metallurgical $\mathrm{Zn}$ production is of particular interest to overcome the main issues of the conventional process.

First studies on $\mathrm{ZnO}$ reduction with methane by thermodynamic analysis $[39,42]$ showed that a chemical equilibrium composition with a single gas phase of $\mathrm{Zn}$ and syngas (with an $\mathrm{H}_{2} / \mathrm{CO}$ ratio of two) was possible at $927{ }^{\circ} \mathrm{C}$. A $5-\mathrm{kW}$ vortex flow reactor for the $\mathrm{ZnO}+\mathrm{CH}_{4}$ system was developed to show its technical feasibility [43], and was further tested at different temperatures $\left(950-1200{ }^{\circ} \mathrm{C}\right)$ [44] but encountered inefficient reactant conversion. Besides, an excess of methane to react with $\mathrm{ZnO}$ downgraded solar energy conversion efficiency [45], which can be alleviated by pulsed methane feeding [45]. However, a thermodynamic study [36] reported that lack of methane resulted in only metallic Zn rather 
than co-production of $\mathrm{Zn}$ and syngas. Ale Ebrahim and Jamshidi [26] showed the possibility of simultaneous metallic zinc and syngas production by thermogravimetry. A thermodynamic study of the chemical looping methane reforming using $\mathrm{ZnO}$ as an oxygen carrier was conducted [46], resulting in a predicted solar-to-fuel energy conversion efficiency up to $76.7 \%$ (at a reduction temperature of $927{ }^{\circ} \mathrm{C}$ and oxidation temperatures of $287-427{ }^{\circ} \mathrm{C}$ ). Recently, Chuayboon and Abanades [47] experimentally demonstrated the on-sun $\mathrm{ZnO}$ reduction with methane in a packed-bed chemical reactor operated in batch mode under vacuum and atmospheric pressure. The pressure reduction enhanced $\mathrm{ZnO}$ conversion but favored $\mathrm{CO}_{2}$ formation due to gas residence time decrease, and increasing the temperature led to carbon formation (alleviated by pressure reduction).

From the above studies, it can be summarized that solar-driven $\mathrm{ZnO}$ reduction with methane is an attractive pathway for $\mathrm{CO}_{2}$-free methane-to-syngas conversion and $\mathrm{Zn}$ production. Some experimental studies were mostly devoted to the solar process feasibility, and the system was operated in batch mode. The performance of such a system under continuous process operation was never investigated before. This study thus aims to demonstrate the process feasibility under real concentrated solar radiation during continuous operation, and to further investigate the reaction scheme (products yields, reactants conversion) and the solar reactor performance (efficiencies). Moreover, it provides new insights on an original thermochemical approach for both syngas and pure metal production in a single process. A particle-fed consuming-bed solar reactor was designed and operated with continuous reactants co-feeding (both $\mathrm{CH}_{4}$ and $\mathrm{ZnO}$ particles) and products extraction from the reactor (both syngas and $\mathrm{Zn}$ ).

During continuous operation, reactant feeding rate plays a key role in chemical reaction and reactor performance. Low reactant feeding rate with respect to reactor capacity may result in low production rate and inefficient solar energy utilization. In contrast, an 
excessively high reactant feeding rate may result in incomplete chemical conversion and reactant accumulation in the reactor. Therefore, the optimal reactant feeding rate maximizing syngas yield and reactor performance must be experimentally assessed.

This study aims to assess the performance of a continuously-operated solar chemical reactor for methane-driven $\mathrm{ZnO}$ reduction using concentrated solar energy as the hightemperature process heat source. The main objective was to demonstrate continuous selective oxidation of methane to syngas and simultaneous reduction of $\mathrm{ZnO}$ to $\mathrm{Zn}$ under highlyconcentrated solar radiation. The combined process was demonstrated in a continuously-fed solar reactor under real solar irradiation conditions and the impact of the key operating conditions was highlighted for both syngas and metal commodity production. The optimal system performance was determined by varying the key parameters including $\mathrm{CH}_{4} / \mathrm{ZnO}$ molar ratio, operating temperature, and reactant feeding rate. The experimental results were achieved under representative real conditions, which provided advancing knowledge in process reliability and stability. The optimal reactant feeding rate and $\mathrm{Zn}$ product characterization were underlined.

\section{Experimental setup and methods}

The schematic diagram of the experimental reactor setup is shown in Fig. 1. The system consists of a prototype continuous solar reactor coupled with a real solar concentrating system composed of a $4-\mathrm{m}^{2}$ automatic sun-tracking heliostat, shutter, and 2-m diameter facedown parabolic dish concentrator (PROMES-CNRS laboratory, Odeillo, France). It was designed to study the on-sun continuous $\mathrm{ZnO}$ reduction combined with methane reforming. Sunlight is reflected by the heliostat toward the concentrator (focal distance: $0.85 \mathrm{~m}$, peak 
flux density: $10.5 \mathrm{MW} / \mathrm{m}^{2}$ for direct normal irradiation (DNI) of $1000 \mathrm{~W} / \mathrm{m}^{2}$ ). Then, highflux concentrated solar radiation is focused in the downward direction to the solar reactor.

The solar reactor consists of a vertical-axis cylindrical cavity receiver made of alumina $\left(121.4 \mathrm{~cm}^{3}\right.$ volume) enveloped with a porous alumino-silicate ceramic insulation layer (40 mm-thick). The outer cylindrical water-cooled reactor shell is made of stainless steel $(2.67 \mathrm{~L}$ volume). A mixture of methane and inert $\mathrm{N}_{2}$ carrier gas is injected from the cavity bottom to flow into the reaction chamber. An alumina wool layer (10 mm thickness) and a bed of inert alumina particles (2-mm diameter, $3 \mathrm{~mm}$ height) are installed at the cavity bottom to favor uniform distribution of methane over the whole cavity section in which $\mathrm{ZnO}$ particles are continuously fed. Concentrated solar energy is absorbed by the reactor cavity receiver via a 17-mm diameter aperture in the alumina front plate. A hemispherical transparent Pyrex glass window is fixed to the front flange of the reactor to operate in controlled atmosphere.

The reaction temperature is monitored thanks to an alumina-shielded B-typethermocouple in the cavity receiver $\left(T_{1}\right)$ and a solar-blind pyrometer $\left(T_{\text {pyrometer }}\right)$ positioned at the parabolic dish center, which directly points to the cavity bottom. In addition, the cavity pressure $(P)$ is measured with a pressure transducer. Protective and carrier gases $\left(\mathrm{N}_{2}\right.$, 99.999\% purity), and reactive gas $\left(\mathrm{CH}_{4}, 99.999 \%\right.$ purity) flow-rates are electronically regulated with mass flow controllers (Brooks, range $0-5 \mathrm{NL} / \mathrm{min} \pm 0.2 \%$ of full scale).

Prior to the experiment, a $\mathrm{ZnO}$ particle delivery system (composed of a screw conveyor driven by an electrical motor) was calibrated to deliver the targeted $\mathrm{ZnO}$ feeding rate. Then, a given amount of $\mathrm{ZnO}$ powder (99.8\% chemical purity, 1-5 $\mu \mathrm{m}$ particle size, purchased from PROLABO) was placed into a hopper (1.15 L volume). The reactor was flushed with $\mathrm{N}_{2}$ and concomitantly sucked with a Venturi pump to remove residual air and maintain a constant pressure in the system. 


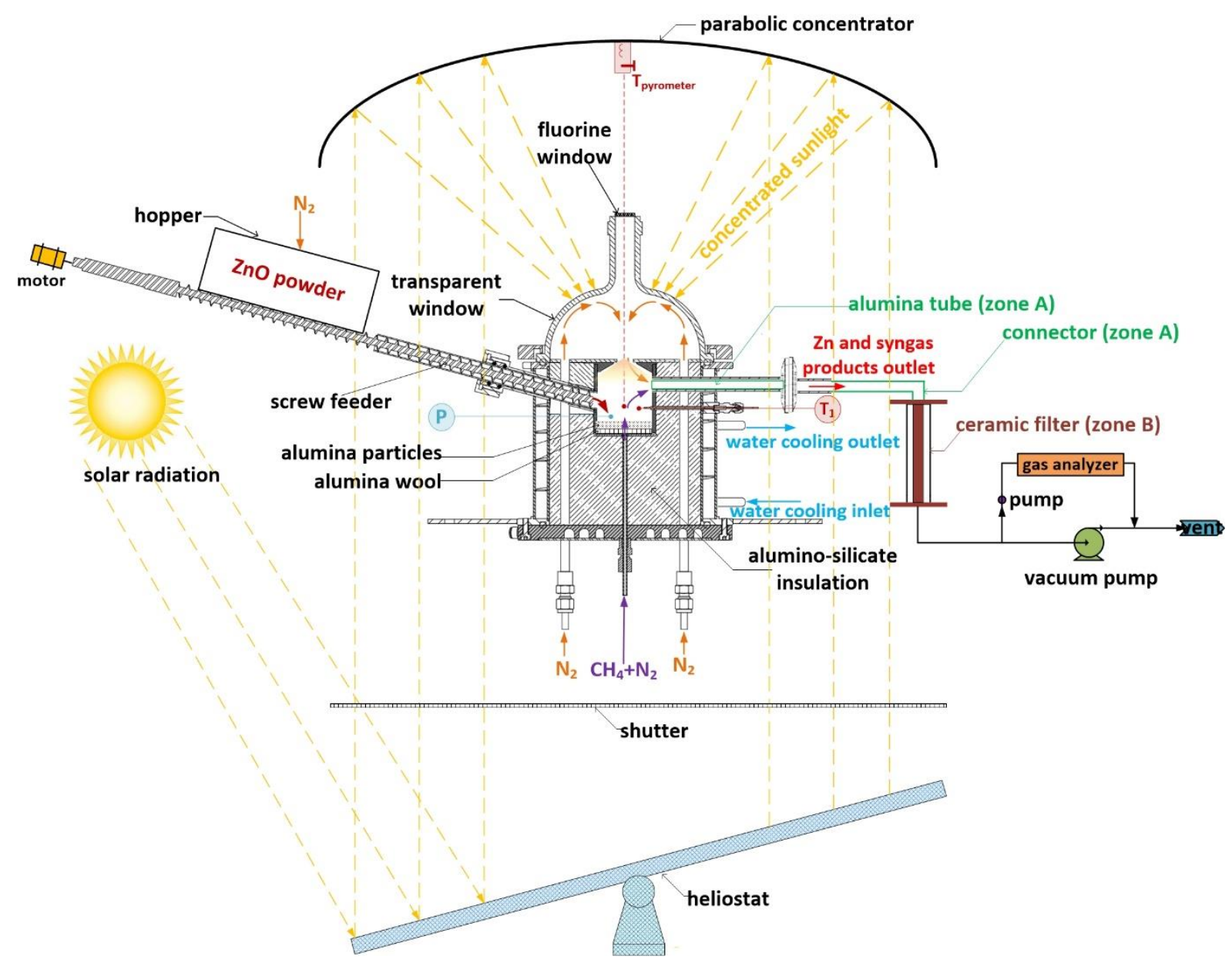

Fig. 1. Schematic diagram of the experimental setup.

During a typical solar run, the reactor was heated progressively with a heating rate of $\sim 30-40{ }^{\circ} \mathrm{C} / \mathrm{min}$, resulting in $42 \mathrm{~min}$ of heating duration (Fig. 2a). The DNI tended to increase slightly, with values in the range $915-972 \mathrm{~W} / \mathrm{m}^{2}$ over the test (Fig. 2b). To protect the transparent reactor window from $\mathrm{Zn}$ product deposition, a protective $\mathrm{N}_{2}$ gas flow (3.5 $\mathrm{NL} / \mathrm{min}$ ) was introduced via two vertical stainless-steel tubes from the bottom of the reactor toward the window area (Fig. 1). After reaching the targeted reaction temperature $\left(1000{ }^{\circ} \mathrm{C}\right.$, Fig. 2a), methane was injected along with carrier $\mathrm{N}_{2}$ flow $(0.2 \mathrm{NL} / \mathrm{min})$ via an alumina tube (2 mm I.D.). In the meantime, $\mathrm{ZnO}$ particles were injected along with carrier $\mathrm{N}_{2}$ flow $(0.5$ $\mathrm{NL} / \mathrm{min}$ ) inside the hot cavity chamber at given feeding rate until complete load injection, resulting in continuous $\mathrm{ZnO}+\mathrm{CH}_{4}$ reaction. To maintain isothermal operation, the solar power 
input can be adjusted with a manual shutter (Fig. 1) in the range of 0.71-0.88 kW (Fig. 2b). As a result, the temperature measured by the thermocouple inside the reactor cavity $\left(T_{1}\right)$ was very well controlled and stable around the temperature set-point. The pyrometer measurement fluctuated due to the continuous particle injection (particles falling continuously inside the cavity indeed affected the pyrometry measurement). The cavity absolute pressure was $\sim 0.86$ bar (atmospheric pressure at the solar facilities located at $1600 \mathrm{~m}$ altitude above sea level) during heating period and then increased slightly to $\sim 0.90$ bar (slightly above atmospheric pressure) during reaction (Fig. 2a). Indeed, the generation of gas species (both syngas and $\mathrm{Zn}(\mathrm{g}))$ increased the pressure slightly, which was monitored continuously in the cavity. 

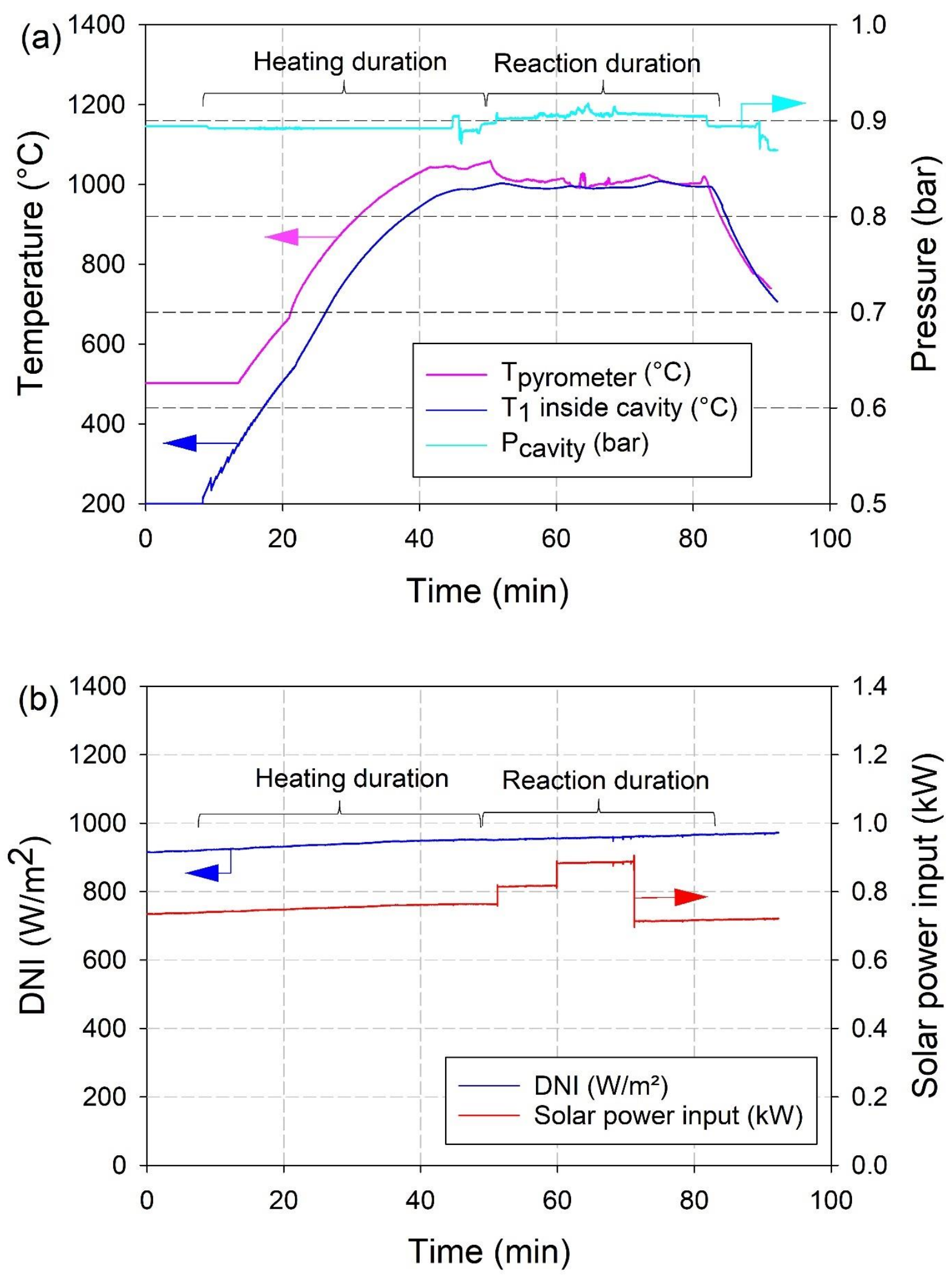

Fig. 2. (a) Temperature and pressure evolution profiles in the reactor chamber and (b) DNI and solar power input during solar heating and continuous reactant injection (Run No.9: 
temperature $=1000{ }^{\circ} \mathrm{C}, \mathrm{ZnO}$ feeding rate $=1.0 \mathrm{~g} / \mathrm{min}, \mathrm{CH}_{4}$ flow rate $=0.4 \mathrm{NL} / \mathrm{min}, \mathrm{CH}_{4} / \mathrm{ZnO}$ molar ratio $=1.5)$.

A mixture of syngas and $\mathrm{Zn}$ vapor left the reactor cavity outlet and passed through a water-cooled alumina outlet tube (where $\mathrm{Zn}$ vapor first condensed) and then a ceramic filter (where condensed $\mathrm{Zn}$ and some soot particles were deposited). The metal was thus recovered at the reactor outlet after a vapor condensation process of the Zn product, thereby enabling insitu extraction and separation of $\mathrm{Zn}$ product from $\mathrm{ZnO}$ feedstock. Prior to gas analysis, the syngas product was cleaned with a microfilter $(0.1 \mu \mathrm{m}$ pore diameter $)$. Subsequently, the reaction gas products $\left(\mathrm{H}_{2}, \mathrm{CO}, \mathrm{CO}_{2}, \mathrm{CH}_{4}\right)$ were quantitatively analyzed with a continuous gas analyzer to determine the syngas composition (Emerson X-STREAM XEGP). The molar flow-rate of gas product species $\left(F_{i}\right)$ was calculated from their outlet mole fraction $\left(y_{i}\right)$ and the inlet $\mathrm{N}_{2}$ molar flow-rate $\left(F_{N_{2}}\right): F_{i}=F_{N_{2}} \cdot y_{i} / y_{N_{2}}$. The syngas yields were then calculated from time integration of the gas production rates $\left(F_{i}\right)$ over the experiment duration. The solid products from the ceramic filter were characterized by X-ray diffraction (XRD) using $\mathrm{Cu} K \alpha$ radiation (PANalytical XPert Pro diffractometer with tube current of $20 \mathrm{~mA}$, potential of 40 $\mathrm{kV}, \lambda=0.15418 \mathrm{~nm}$, step size $=0.02^{\circ}$, time per step $=2 \mathrm{~s}$, angular range $\left.=15-75^{\circ} 2 \theta\right)$ for species phase identification, while their morphology was characterized by field emission scanning electron microscopy (FESEM, Hitachi S4800, acceleration voltage of 5-10 kV).

According to previous thermodynamic [42] and experimental studies [43], some $\mathrm{H}_{2} \mathrm{O}$ is generated according to Eq. 2 during the $\mathrm{ZnO}+\mathrm{CH}_{4}$ reaction. However, it was not measured by gas analysis. The generated $\mathrm{H}_{2} \mathrm{O}$ was calculated both from the amount of $\mathrm{CO}_{2}$ (Eq. 2) and by hydrogen atom balance (Eq. 3).

$$
4 \mathrm{ZnO}+\mathrm{CH}_{4} \rightarrow 4 \mathrm{Zn}+\mathrm{CO}_{2}+2 \mathrm{H}_{2} \mathrm{O} \quad\left(\Delta \mathrm{H}^{\circ}=1121.04 \mathrm{~kJ} / \mathrm{mol}, \mathrm{T}_{\left(@ \Delta \mathrm{G}^{\circ}=0\right)}=1044^{\circ} \mathrm{C}\right)
$$




$$
\left(4 n_{\mathrm{CH}_{4}}\right)_{\text {inlet }}=\left(2 n_{\mathrm{H}_{2}}+4 n_{\mathrm{CH}_{4}}+2 n_{\mathrm{H}_{2} \mathrm{O}}\right)_{\text {outlet }}
$$

where $n_{i}$ represents the mole amount of species $i$.

In addition, the side reaction associated with methane cracking can concomitantly take place, yielding solid carbon or soot and $\mathrm{H}_{2}$ as follows:

$$
\mathrm{CH}_{4} \rightarrow \mathrm{C}+2 \mathrm{H}_{2} \quad\left(\Delta \mathrm{H}^{\circ}=74.6 \mathrm{~kJ} / \mathrm{mol}, \mathrm{T}_{\left(@ \Delta \mathrm{G}^{\circ}=0\right)}=547^{\circ} \mathrm{C}\right)
$$

To determine the amount of solid carbon derived from Eq. 4, a carbon atom balance was applied as follows:

$$
\left(n_{\mathrm{CH}_{4}}\right)_{\text {inlet }}=\left(n_{\mathrm{C}}+n_{\mathrm{CO}}+n_{\mathrm{CO}_{2}}+n_{\mathrm{CH}_{4}}\right)_{\text {outlet }}
$$

The calculated amount of solid carbon from Eq. 5 was used to calculate the additional $\mathrm{H}_{2}$ produced from methane cracking (Eq. 4), which is twice the amount of solid carbon.

The $\mathrm{H}_{2}$ and $\mathrm{CO}$ selectivity were calculated as follows:

$$
\begin{aligned}
S_{H_{2}} & =\frac{n_{H_{2}}}{n_{\mathrm{H}_{2}}+n_{\mathrm{H}_{2} \mathrm{O}}} \\
S_{\mathrm{CO}} & =\frac{n_{\mathrm{CO}}}{n_{\mathrm{CO}}+n_{\mathrm{CO}_{2}}}
\end{aligned}
$$

The $\mathrm{ZnO}$ conversion $\left(X_{Z n O}\right)$ represents the $\mathrm{Zn}$ yield or converted lattice oxygen per mole of $\mathrm{ZnO}$, and was calculated as follows: 


$$
X_{Z n O}=\frac{n_{C O}+2 n_{\mathrm{CO}_{2}}+n_{\mathrm{H}_{2} \mathrm{O}}}{n_{\mathrm{ZnO}}}
$$

The $\mathrm{CH}_{4}$ conversion $\left(\mathrm{X}_{\mathrm{CH} 4}\right)$ was determined as follows:

$$
X_{\mathrm{CH}_{4}}=1-\frac{\dot{m}_{\text {unreacted } \mathrm{CH}_{4}}}{\dot{m}_{\mathrm{CH}_{4}}}
$$

where $\dot{m}_{\text {unreacted } \mathrm{CH}_{4}}$ and $\dot{m}_{\mathrm{CH}_{4}}$ represent the mass flow-rates of unreacted methane and injected methane, respectively.

The carbon conversion factor $\left(X_{C}\right)$ represents the ratio of the total amount of carbon contained in the outlet product gases to the initial carbon in injected methane:

$$
X_{C}=\frac{\int_{0}^{t} F_{C O}(t) d t+\int_{0}^{t} F_{C O_{2}}(t) d t+\int_{0}^{t} F_{\text {unreacted }} \mathrm{CH}_{4}(t) d t}{\int_{0}^{t} F_{\text {injected }} \mathrm{CH}_{4}(t) d t}
$$

$F_{i}$ represents the molar flow-rate of species i (mol/s).

The solar reactor performance metrics are represented by the energy upgrade factor $(U)$ and solar-to-chemical energy conversion efficiency $\left(\eta_{\text {solar-to-fuel }}\right)$.

$$
\begin{gathered}
U=\frac{\left(\dot{m}_{H_{2}} \cdot L H V_{H_{2}}+\dot{m}_{C O} \cdot L H V_{C O}\right)+\left(\left(1-X_{C H_{4}}\right) \cdot \dot{m}_{C H_{4}} \cdot L H V_{C H_{4}}\right)+\left(\dot{m}_{Z n} \cdot L H V_{Z n}\right)}{\left(\dot{m}_{C H_{4}} \cdot L H V_{C H_{4}}\right)} \\
\eta_{\text {solar-to-fuel }}=\frac{\left(\dot{m}_{H_{2}} \cdot L H V_{H_{2}}+\dot{m}_{C O} \cdot L H V_{C O}\right)+\left(\dot{m}_{Z n} \cdot L H V_{Z n}\right)}{\dot{Q}_{\text {solar }}+\left(X_{C H_{4}} \cdot \dot{m}_{C H_{4}} \cdot L H V_{C H_{4}}\right)}
\end{gathered}
$$

where $\dot{m}$ is the mass flow-rate $(\mathrm{kg} / \mathrm{s}), L H V$ is the Lower Heating Value $(\mathrm{J} / \mathrm{kg})$, and $\dot{Q}_{\text {solar }}$ is the total solar power input absorbed by the reactor cavity (power entering the cavity via the 
aperture) (W), respectively. This efficiency can also be expressed in terms of heat energy if the masses of gas products are used in Eq. (12) instead of flow rates.

\section{Results and discussion}

\subsection{Solar reactor performance assessment}

The operating conditions and experimental results of continuous methane-driven $\mathrm{ZnO}$ reduction for performed on-sun runs are reported in Table 1. The influence of the operating parameters (temperature, reactant molar ratio, and feeding rate) was thoroughly investigated. The following parameter ranges were used in the experiments: initial $\mathrm{ZnO}$ mass $=10 \mathrm{~g}$ and $20 \mathrm{~g}, \mathrm{ZnO}$ feeding rate $\left(\dot{m}_{Z n O}\right)=0.5-1.5 \mathrm{~g} / \mathrm{min}$, inlet methane flow rate $\left(\dot{m}_{C H 4}\right)=0.2-0.6$ $\mathrm{NL} / \mathrm{min}$, temperature $\left(T_{1}\right)=900-1000{ }^{\circ} \mathrm{C}, \mathrm{CH}_{4} / \mathrm{ZnO}$ molar ratio $=1-1.5$, total inlet $\mathrm{N}_{2}$ flow rate $\left(\dot{m}_{N_{2}}\right)=4.2 \mathrm{NL} / \mathrm{min}$, and solar power input $\left(\dot{Q}_{\text {solar }}\right)=0.67-0.84 \mathrm{~kW}_{\text {th. }}$. Repeatability tests were further performed to confirm the data reliability. Run\#1 and Run\#2 were performed with the same parameters as well as Run\#4 and Run\#5 (and further repeated twice), and their results were found to be comparable, according to Fig. S1 (Run\#1 vs. Run\#2 at $900^{\circ} \mathrm{C}$ ) and Fig. S2 (Run\#4 vs. Run\#5 at $950^{\circ} \mathrm{C}$ ) (Supplementary Material), demonstrating experimental repeatability. Run\#5 was performed with $20 \mathrm{~g}$ of $\mathrm{ZnO}$ to demonstrate long-run continuous operation.

Syngas yields were calculated by time integration of gas output production rates using $\mathrm{N}_{2}$ flow rate as the dilution gas. The yields of $\mathrm{H}_{2}, \mathrm{CO}$, and $\mathrm{CO}_{2}$ were in the range 5.95-15.20, 2.09-3.47, and 0.74-1.26 mmol/g $/ \mathrm{gnO}_{\mathrm{Zn}}$, with $\mathrm{H}_{2}$ and $\mathrm{CO}$ selectivity of $0.76-0.86$ and $0.69-0.79$, respectively, resulting in $\mathrm{H}_{2} / \mathrm{CO}$ ratios in the range 2.5-4.4, suitable for liquid fuel synthesis process. According to Eq. 2, generated water was found in the range of $1.5-2.5 \mathrm{mmol} / \mathrm{g}_{\mathrm{ZnO}}$, comparable with the results obtained from $\mathrm{H}$-atom balance (Eq. 3) $\left(0.9-2.5 \mathrm{mmol} / \mathrm{g}_{\mathrm{ZnO}}\right)$. 
According to Eq. 5, C (solid carbon) yield was in the range of 0.05-3.91 $\mathrm{mmol} / \mathrm{g}_{\mathrm{ZnO}}$, thereby resulting in $\mathrm{H}_{2}$ yield from methane cracking in the range of $0.10-7.82 \mathrm{mmol} / \mathrm{g}_{\mathrm{ZnO}}$. At $900{ }^{\circ} \mathrm{C}$, values of $\mathrm{C}$ yield were found to be negligible.

$\mathrm{ZnO}$ conversion $\left(X_{\mathrm{ZnO}}\right)$ and methane conversion $\left(X_{C H 4}\right)$ were $46.5-69.1 \%$ and $4.4-$ $14.6 \%$, respectively. The maximum $X_{Z n O}$ and $X_{C H 4}$ values were found at the highest temperature, pointing out a strong temperature dependence. In fact, incomplete $X_{Z n O}$ was due to partial $\mathrm{ZnO}$ reduction reaction (as evidenced by some $\mathrm{ZnO}$ remaining in the cavity receiver, Fig. S3), but also to recombination reactions at the outlet (according to Fig. S4). The global mass balance was in the range $80.7-95.2 \%$ (Table S1). The remaining mass was ascribed to the $\mathrm{ZnO}$ remaining in the reactor (not quantified and thus not taken into account in the mass balance). Improving the $\mathrm{CH}_{4}$ conversion was not targeted because $\mathrm{CH}_{4}$ was injected continuously even during the initial period without $\mathrm{ZnO}$ injection. It is thus normal that the $\mathrm{CH}_{4}$ conversion remained low in the tests. This is not an obstacle for the process, since the $\mathrm{CH}_{4}$ conversion could be increased drastically by increasing the gas-solid contact time between $\mathrm{CH}_{4}$ and $\mathrm{ZnO}$ (with suitable reactor design) and by process scale-up (increase of the reaction chamber volume for enhanced residence time). For example, in an optimized process, $\mathrm{ZnO}$ and $\mathrm{CH}_{4}$ could be injected in a countercurrent reactor to enhance the solid-gas contact time, which in turn would improve the $\mathrm{CH}_{4}$ conversion.

The carbon conversion factor $\left(X_{C}\right)$ approached $100 \%$ (93.4-99.9\%), confirming the low solid carbon formation. The energy upgrade factor $(U)$ was greater than one (1.04-1.13) for all tests, demonstrating efficient solar energy storage into chemical products. Assuming ideal reaction based on Eq. 1, the upper bound limit of the energy upgrade factor would be 1.39. Solar-to-fuel energy conversion efficiency $\left(\eta_{\text {solar-to-fuel }}\right)$ was in the range of $3.2-6.6 \%$, thus outperforming those values derived from batch operation (1.9-3.3\%) [47], and demonstrating the significant benefit of continuous operation. This efficiency could be 
drastically increased via process scale-up, which inherently would reduce the heat losses for better utilization of the solar power input devoted to the reaction. Secondly, the experimental runs were performed with low amounts of solid $\mathrm{ZnO}$ feedstock in the hopper. It can be anticipated that longer runs with much higher $\mathrm{ZnO}$ amount would increase the efficiency, as suggested by the enhanced efficiency of Run\#5 performed with $20 \mathrm{~g}$ of $\mathrm{ZnO}$ (instead of 10 g).

Table 1. Operating conditions and experimental solar reactor performance during on-sun continuous methane-driven $\mathrm{ZnO}$ reduction.

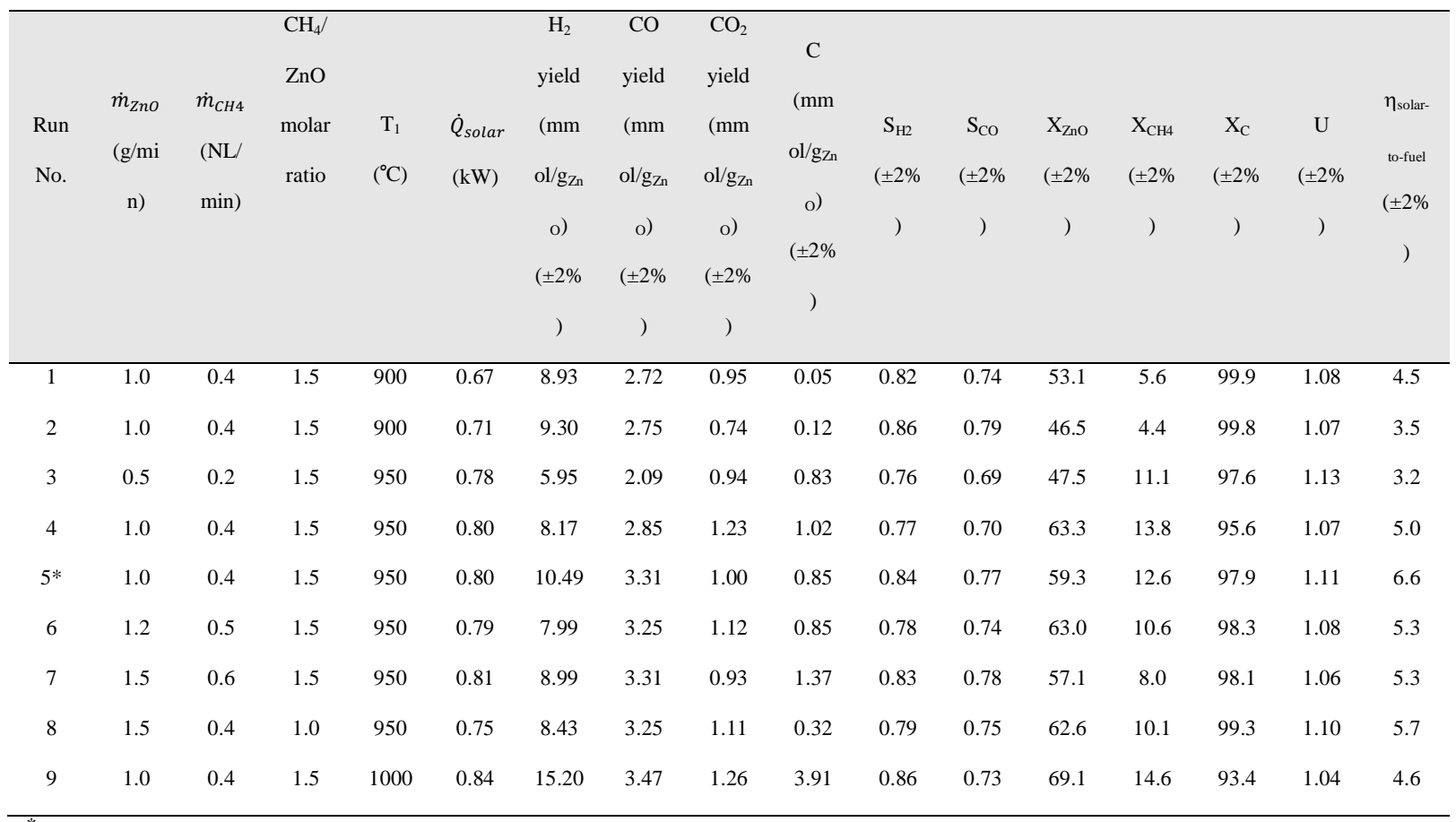

*Initial $\mathrm{ZnO}$ mass $=20 \mathrm{~g}$

\subsection{Demonstration of continuous methane-driven $\mathrm{ZnO}$ reduction process}

A proof-of-concept on-sun experiment with long and stable continuous injection was performed to demonstrate the feasibility of continuous methane-driven $\mathrm{ZnO}$ reduction process. $\mathrm{ZnO}$ powder (20 g initial mass) was first loaded into the hopper of the reactant 
feeding delivery system. $\mathrm{ZnO}$ and methane feeding rates were set at $1.0 \mathrm{~g} / \mathrm{min}$ and 0.4 $\mathrm{NL} / \mathrm{min}$, respectively, resulting in a constant $\mathrm{CH}_{4} / \mathrm{ZnO}$ molar ratio of 1.5 (Run\#5). The experiment was conducted under isothermal condition of $950{ }^{\circ} \mathrm{C}$ at atmospheric pressure with a test duration lasting $48 \mathrm{~min}$ (Fig. 3). The reactor temperatures $\left(T_{1}\right.$ and $\left.T_{\text {pyrometer }}\right)$ were constant and close, indicating homogeneous reactor temperature and isothermal operation. $\mathrm{CH}_{4}$ was first injected in the reactor cavity (explaining formation of $\mathrm{H}_{2}$ at the beginning), followed by $\mathrm{ZnO}$ injection while keeping the $\mathrm{CH}_{4}$ flow. Syngas was continuously produced until complete $\mathrm{ZnO}$ injection in the reactor cavity, highlighting the reliability and robustness of the system. The reaction was carried out within approximately 36 min duration (counting from first detection of $\mathrm{CO}$ in the analysis of the gaseous product stream till $\mathrm{CO}$ reaching zero), while the expected duration was $20 \mathrm{~min}$ (for $\mathrm{ZnO}$ feeding rate of $1.0 \mathrm{~g} / \mathrm{min}$ ), suggesting kinetic limitation and temporal $\mathrm{ZnO}$ accumulation during the reaction. After the experiment, some small pieces of $\mathrm{ZnO}$ remaining in spiral shape were observed as a result of powder packing inside the screw conveyor. A slight and relative fluctuation of the syngas production rate consistent with $T_{\text {pyrometer }}$ was observed, attributed to instabilities in $\mathrm{ZnO}$ feeding rate caused by the screw feeding system.

The $\mathrm{H}_{2}, \mathrm{CO}, \mathrm{CO}_{2}$, and $\mathrm{C}$ yields were found to be $10.49,3.31,1.00$, and 0.85 $\mathrm{mmol} / \mathrm{g}_{\mathrm{ZnO}}$, thus comparable with the results from Run\#4 (Table 1) performed under the same initial conditions and confirming repeatability. $\mathrm{H}_{2}$ and $\mathrm{CO}$ selectivity were 0.84 and 0.77 , respectively. Regarding reactor performance, $X_{\mathrm{ZnO}}$ of $59.3 \%$ and $X_{\mathrm{CH} 4}$ of $12.6 \%$ were obtained while $U$ of 1.11 and $\eta_{\text {solar-to-fuel }}$ of $6.6 \%$ were achieved. Global mass balance was $\sim 90 \%$. This test proved the practical feasibility of the continuously-fed solar reactor for the co-production of $\mathrm{Zn}$ and syngas in a single process. 


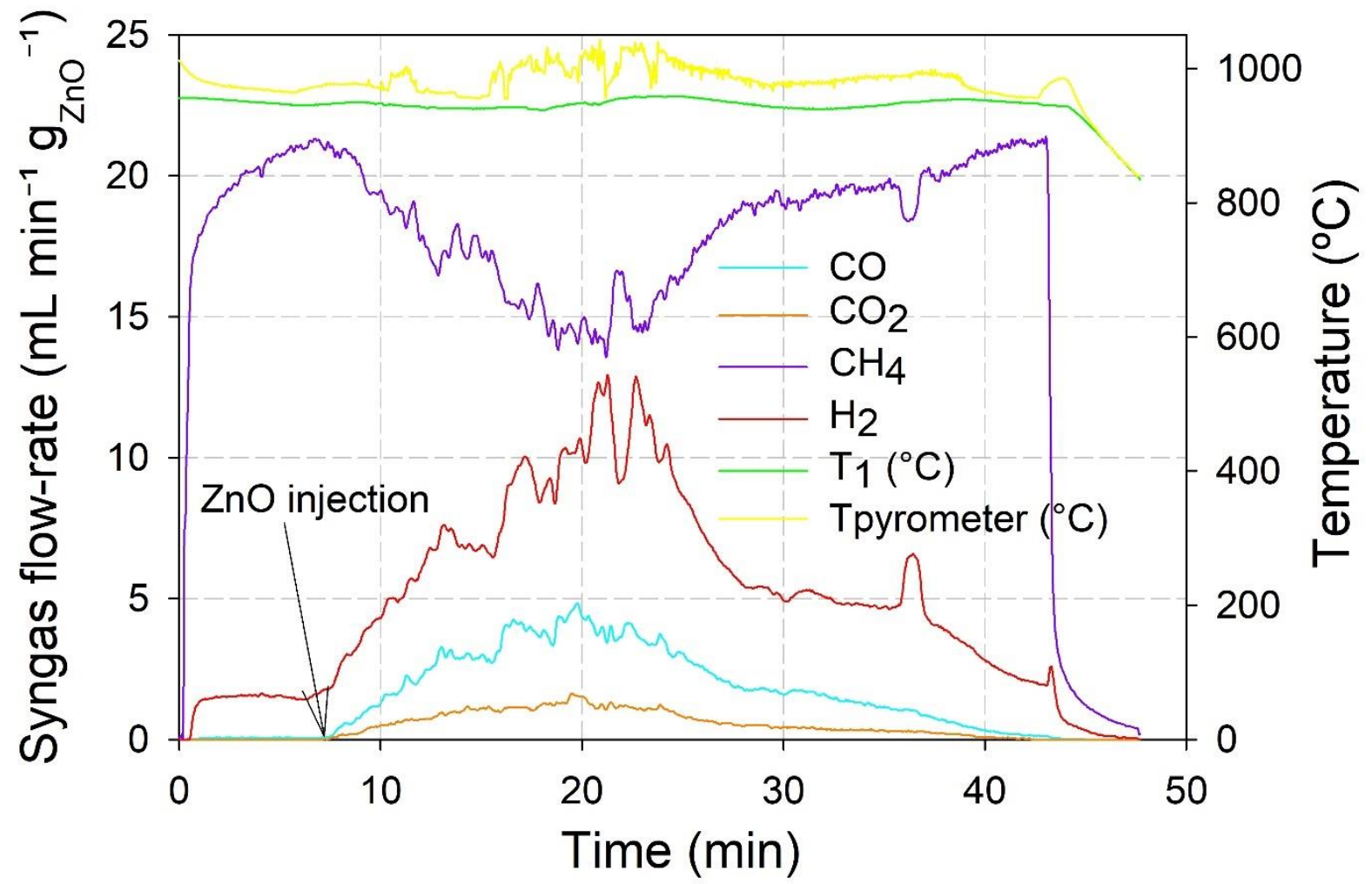

Fig. 3. Outlet syngas species production rates along with reactor chamber temperatures $\left(T_{1}\right.$ and $\left.T_{\text {pyrometer }}\right)$ during continuous methane-driven $\mathrm{ZnO}$ reduction with $20 \mathrm{~g}$ of $\mathrm{ZnO}$ powder (Run\#5: temperature $=950{ }^{\circ} \mathrm{C}, \mathrm{ZnO}$ feeding rate $=1.0 \mathrm{~g} / \mathrm{min}$, inlet $\mathrm{CH}_{4}$ flow rate $=0.4$ $\mathrm{NL} / \mathrm{min}, \mathrm{CH}_{4} / \mathrm{ZnO}$ molar ratio $\left.=1.5\right)$.

\subsection{Influence of inlet $\mathrm{CH}_{4} / \mathrm{ZnO}$ molar ratio}

Continuous methane-driven $\mathrm{ZnO}$ reduction was experimentally carried out to investigate the effect of $\mathrm{CH}_{4} / \mathrm{ZnO}$ ratio on syngas production rate and yield at $950{ }^{\circ} \mathrm{C}$ ( $\mathrm{Run} \# 8$ vs. Run\#7). Inlet $\mathrm{ZnO}$ feeding rate was kept constant at $1.5 \mathrm{~g} / \mathrm{min}$ while inlet $\mathrm{CH}_{4}$ flow rate was adjusted at $0.40 \mathrm{NL} / \mathrm{min}$ and $0.60 \mathrm{NL} / \mathrm{min}$, which resulted in $\mathrm{CH}_{4} / \mathrm{ZnO}$ molar ratios of 1 (stoichiometric ratio) and 1.5 (50\% over stoichiometric ratio), respectively. A previous study reported that excess methane is necessary to completely react with $\mathrm{ZnO}$ at the expense of 
increased solar energy consumption [45]. Fig. 4 shows syngas production rates along with temperatures $\left(T_{1}\right.$ and $T_{\text {pyrometer }}$ ) at $950{ }^{\circ} \mathrm{C}$, plotted for $\mathrm{CH}_{4} / \mathrm{ZnO}$ molar ratio of 1.0 (Fig. $4 \mathrm{a}$ ) compared to 1.5 (Fig. $4 \mathrm{~b}$ ). $T_{1}$ and $T_{\text {pyrometer }}$ were found to be in good agreement over entire injection, denoting homogeneous reactor temperature.

After injecting methane, $\mathrm{H}_{2}$ was first produced slightly, followed by a mixture of $\mathrm{CO}$ and $\mathrm{CO}_{2}$ when injecting $\mathrm{ZnO}$ (after $\sim 5 \mathrm{~min}$ ), indicating that a small part of methane was first thermally decomposed to $\mathrm{H}_{2}(\mathrm{~g})$ and $\mathrm{C}(\mathrm{s})$. Then, the fed $\mathrm{ZnO}$ partially oxidized methane, resulting in $\mathrm{H}_{2}, \mathrm{CO}$, and $\mathrm{CO}_{2}$ release. The particle injection was continuous until $\mathrm{ZnO}$ had been totally fed inside the reactor. The syngas evolution then decreased progressively until reaching reaction completion. At $\mathrm{CH}_{4} / \mathrm{ZnO}$ ratio $=1.5, \mathrm{H}_{2}, \mathrm{CO}$, and $\mathrm{CO}_{2}$ production rates were slightly greater than those at $\mathrm{CH}_{4} / \mathrm{ZnO}$ ratio $=1.0$, denoting a positive influence of excess methane. In comparison, the global reaction durations were similar, suggesting a small impact of excess methane on reaction kinetics within the considered range. After $\mathrm{CO}$ approaching zero, the inlet methane flow rate was stopped, resulting in a final drop in $\mathrm{H}_{2}$ production rate.
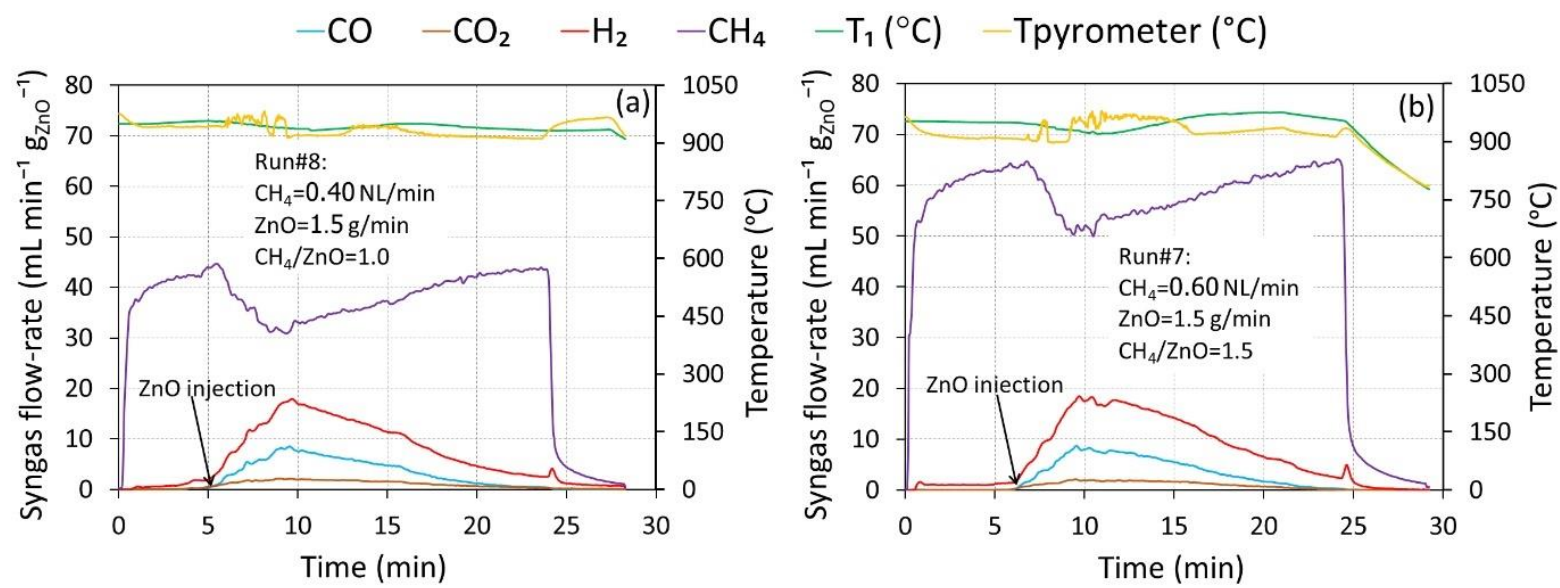

Fig. 4. Evolution of syngas production rates and reactor chamber temperatures $\left(T_{1}\right.$ and $\left.T_{\text {pyrometer }}\right)$ during on-sun continuous methane-driven $\mathrm{ZnO}$ reduction at $950{ }^{\circ} \mathrm{C}$ : (a) $\mathrm{CH}_{4} / \mathrm{ZnO}=$ 1.0 and (b) $\mathrm{CH}_{4} / \mathrm{ZnO}=1.5$. 
Fig. 5 shows the syngas yields $\left(\mathrm{mmol} / \mathrm{g}_{\mathrm{ZnO}}\right)$ calculated from the syngas production rates (Fig. 4). As expected, the excess methane promoted $\mathrm{ZnO}+\mathrm{CH}_{4}$ reaction, as evidenced by an improvement of $\mathrm{H}_{2}$ and $\mathrm{CO}$ yields from 8.44 and $3.25 \mathrm{mmol} / \mathrm{g}_{\mathrm{ZnO}}$ at $\mathrm{CH}_{4} / \mathrm{ZnO}=1.0$ (stoichiometric ratio) to 9.00 and $3.31 \mathrm{mmol} / \mathrm{g}_{\mathrm{ZnO}}$ at $\mathrm{CH}_{4} / \mathrm{ZnO}=1.5$ (over stoichiometric ratio), along with a decrease of $\mathrm{CO}_{2}$ yield from 1.11 at 1 to $0.93 \mathrm{mmol} / \mathrm{g}_{\mathrm{ZnO}}$ (yielding total syngas yield from 12.79 to $13.23 \mathrm{mmol} / \mathrm{g}_{\mathrm{ZnO}}$. However, at $\mathrm{CH}_{4} / \mathrm{ZnO}=1.5$, a drastic rise in the $\mathrm{C}$ (solid carbon) yield, calculated from Eq. 5, was noticed $\left(1.37 \mathrm{mmol} / \mathrm{g}_{\mathrm{ZnO}}\right)$ due to the excess methane that favored the side methane cracking reaction. This thus revealed that excess methane promoted both main and side reactions. Besides, the $\mathrm{H}_{2}$ yield produced from methane cracking reaction $\left(2.74 \mathrm{mmol} / \mathrm{g}_{\mathrm{ZnO}}\right)$ can be calculated from solid carbon yield (twice the solid carbon according to Eq. 4). In fact, methane cracking caused carbon deposition, which may lead to carbon accumulation in the reactor cavity receiver [47]. As expected, a methane excess resulted in improved $X_{\mathrm{ZnO}}\left(62.6 \%\left(\mathrm{CH}_{4} / \mathrm{ZnO}=1.5\right)\right.$ vs. $57.1 \%\left(\mathrm{CH}_{4} / \mathrm{ZnO}=\right.$ 1)), but reduced $X_{\mathrm{CH} 4}\left(8.0 . \%\left(\mathrm{CH}_{4} / \mathrm{ZnO}=1.5\right)\right.$ vs. $\left.10.1 \%\left(\mathrm{CH}_{4} / \mathrm{ZnO}=1\right)\right)$, and slightly downgraded $\eta_{\text {solar-to-fuel }}\left(5.3 \%\left(\mathrm{CH}_{4} / \mathrm{ZnO}=1.5\right)\right.$ vs. $\left.5.7 \%\left(\mathrm{CH}_{4} / \mathrm{ZnO}=1\right)\right)$. For these reasons, the quantity of excess methane needs to be moderate to alleviate such issues. 


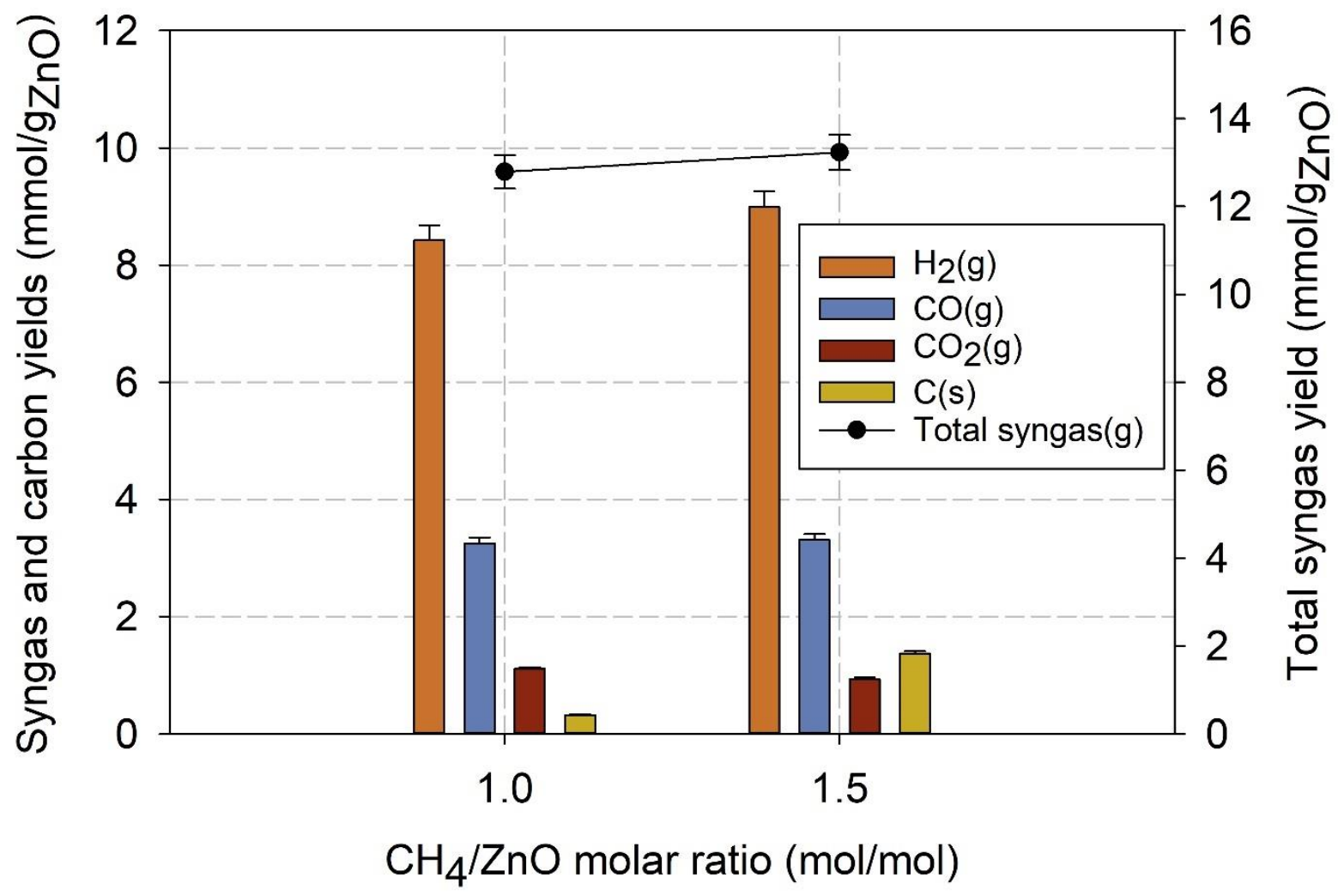

Fig. 5. Impact of $\mathrm{CH}_{4} / \mathrm{ZnO}$ molar ratio on syngas yields at $950{ }^{\circ} \mathrm{C}$.

\subsection{Influence of operating temperature}

The influence of temperature on continuous methane-driven $\mathrm{ZnO}$ reduction was experimentally studied under slightly above atmospheric pressure ( 0.90 bar $)$ and isothermal runs at $900{ }^{\circ} \mathrm{C}$ (Run\#1), $950{ }^{\circ} \mathrm{C}$ (Run\#4), and $1000{ }^{\circ} \mathrm{C}$ (Run\#9). At these temperatures, Zn vapor can be generated and transported by the carrier gas to the reactor outlet for subsequent $\mathrm{Zn}$ powder recovery in the filter (this vaporization-condensation process is advantageous since it allows in-situ $\mathrm{Zn}$ extraction from the reactor cavity and separation from solid $\mathrm{ZnO}$ ). $\mathrm{ZnO}$ powder (10 $\mathrm{g}$ of initial mass) was fed at $1.0 \mathrm{~g} / \mathrm{min}$ while methane flow rate was 0.4 $\mathrm{NL} /$ min, resulting in a $\mathrm{CH}_{4} / \mathrm{ZnO}$ molar ratio of 1.5 (thus promoting $\mathrm{ZnO}+\mathrm{CH}_{4}$ reaction according to results of the previous section). Fig. 6 shows syngas species production rates along with reactor temperatures $\left(T_{l}\right.$ and $\left.T_{\text {pyrometer }}\right)$ at each temperature. As a result, an increase 
in the temperature significantly enhanced syngas production rates, and the maximum syngas production rate was reached at the highest temperature $\left(1000{ }^{\circ} \mathrm{C}\right)$. The peak $\mathrm{H}_{2}, \mathrm{CO}$, and $\mathrm{CO}_{2}$ production rates were $12.36,4.86$, and $1.51 \mathrm{~mL} \mathrm{~min}^{-1} \mathrm{~g}_{\mathrm{ZnO}}{ }^{-1}$ at $900{ }^{\circ} \mathrm{C}$ compared to 19.35 , 7.51, and $2.54 \mathrm{~mL} \mathrm{~min}^{-1} \mathrm{~g}_{\mathrm{ZnO}}{ }^{-1}$ at $1000{ }^{\circ} \mathrm{C}$. At $900{ }^{\circ} \mathrm{C}$, a sharp variation in the temperature was noticed because of cloud passage. This sequentially resulted in unstable syngas production rates and extended reaction duration, while exhibiting a strong correlating dependence of syngas evolution on temperature. 

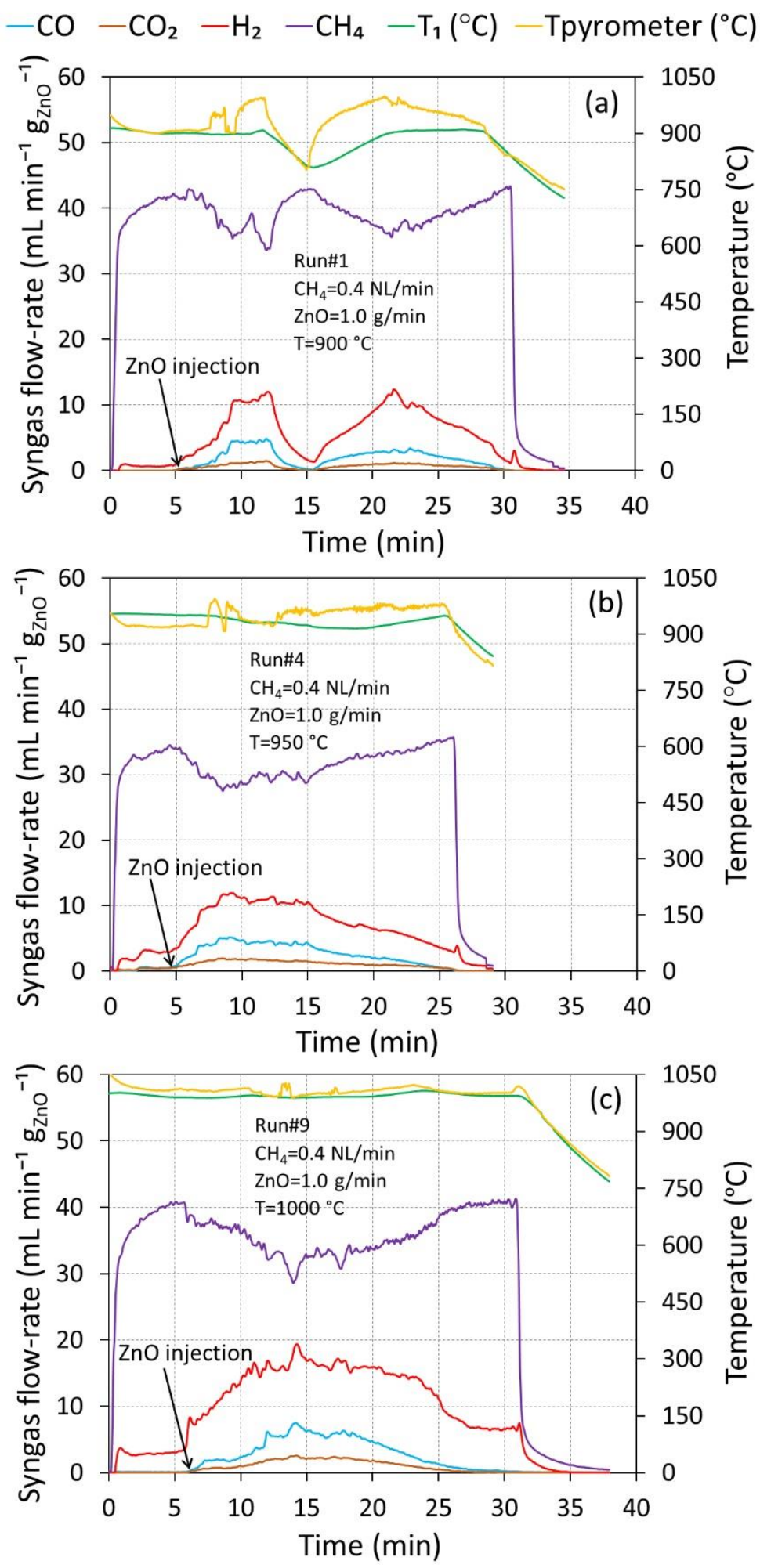

Fig. 6. Evolution of syngas production rates and reactor temperatures $\left(T_{1}\right.$ and $\left.T_{\text {pyrometer }}\right)$ during continuous methane-driven $\mathrm{ZnO}$ reduction at temperatures of (a) 900, (b) 950, and (c) $1000{ }^{\circ} \mathrm{C}$. 
According to Fig. 7, $\mathrm{H}_{2}, \mathrm{CO}$, and $\mathrm{CO}_{2}$ yields were substantially improved when increasing the temperature (from $8.93,2.72$, and $0.95 \mathrm{mmol} / \mathrm{g}_{\mathrm{ZnO}}$ at $900{ }^{\circ} \mathrm{C}$ to $15.20,3.47$, and $1.26 \mathrm{mmol} / \mathrm{g}_{\mathrm{ZnO}}$ at $1000{ }^{\circ} \mathrm{C}$ ), resulting in $\mathrm{H}_{2}$ and $\mathrm{CO}$ selectivity from 0.82 and 0.74 at $900{ }^{\circ} \mathrm{C}$ to 0.86 and 0.73 at $1000{ }^{\circ} \mathrm{C}$, respectively. This concomitantly led to total syngas yield rising significantly from $12.60 \mathrm{mmol} / \mathrm{g}_{\mathrm{ZnO}}\left(900{ }^{\circ} \mathrm{C}\right)$ to $19.92 \mathrm{mmol} / \mathrm{g}_{\mathrm{ZnO}}\left(1000{ }^{\circ} \mathrm{C}\right)$, indicating a positive impact of temperature increase on $\mathrm{ZnO}+\mathrm{CH}_{4}$ reaction extent (Eq. 1). Nevertheless, the $\mathrm{C}$ yield increased with temperature and attained the maximum value of $3.91 \mathrm{mmol} / \mathrm{g}_{\mathrm{ZnO}}$ at $1000{ }^{\circ} \mathrm{C}$, because of the favored methane thermal dissociation resulting in solid carbon/soot deposition. As observed in Fig. 6a, the temperature fluctuation that sometimes exceeded 900 ${ }^{\circ} \mathrm{C}$ led to $\mathrm{H}_{2}$ yield being increased, thus explaining the higher $\mathrm{H}_{2}$ value than that at $950{ }^{\circ} \mathrm{C}$ (Fig. 7). 


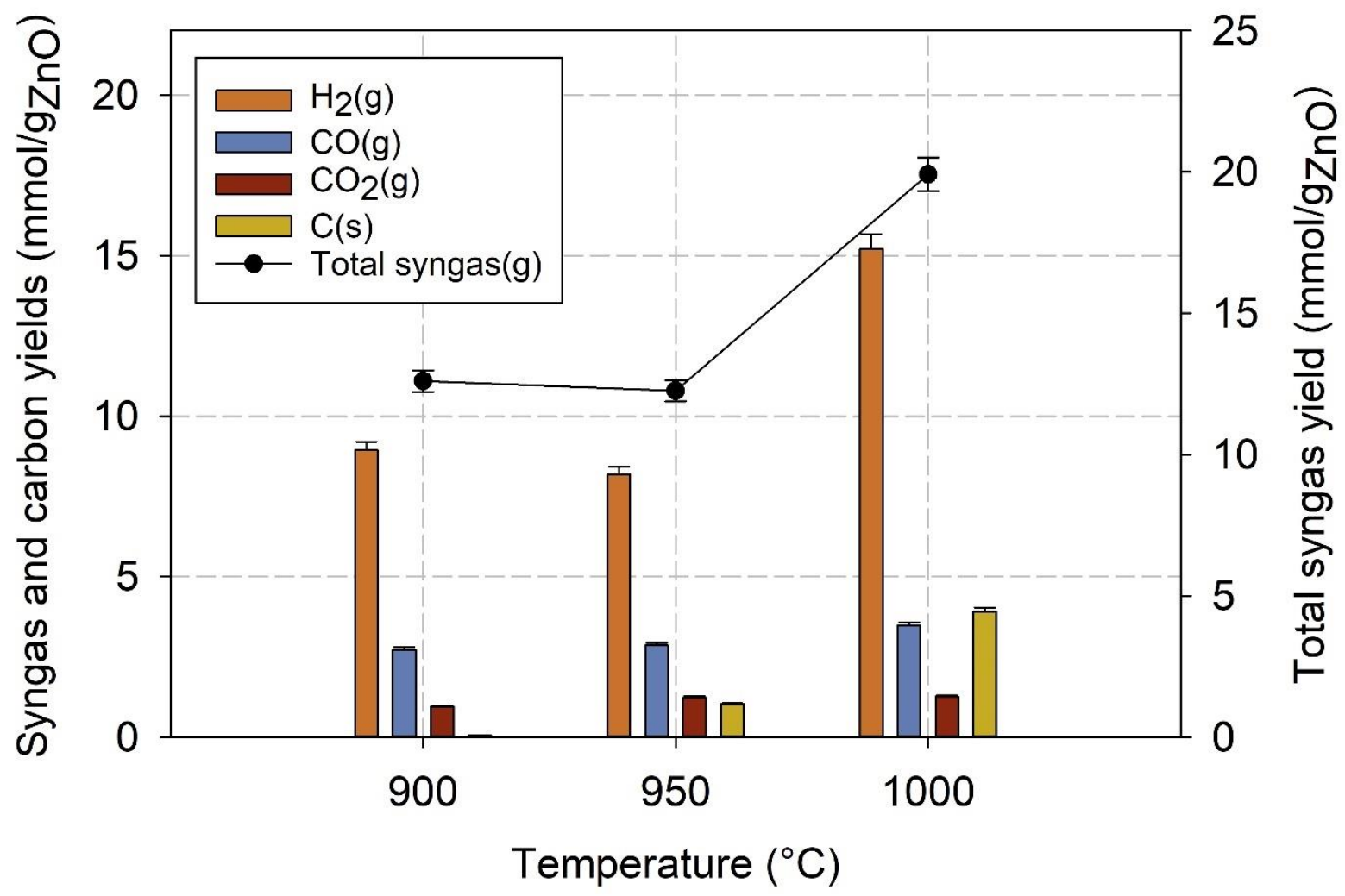

Fig. 7. Impact of temperature on syngas yields.

The $\mathrm{ZnO}$ consumption rate (Fig. 8) was estimated from the summation of the oxygen production rate related to $\mathrm{CO}, \mathrm{CO}_{2}$, and $\mathrm{H}_{2} \mathrm{O}$ products. $\mathrm{ZnO}$ consumption rate increased with temperature from 0.51 to $0.83 \mathrm{~g} / \mathrm{min}$ while $\mathrm{ZnO}$ feeding rate was kept constant at $1 \mathrm{~g} / \mathrm{min}$. This thus clearly demonstrated that the kinetic rate of $\mathrm{ZnO}+\mathrm{CH}_{4}$ was improved when increasing the temperature, with an activation energy of $60.7 \pm 17 \mathrm{~kJ} / \mathrm{mol}$ according to the Arrhenius plot (Fig. S5). The lowest temperature led to the lowest $\mathrm{ZnO}$ consumption rate, which resulted in the remaining unreacted $\mathrm{ZnO}$ in the cavity (Fig. S3). The consumption rate approached the feeding rate when increasing the temperature to $1000^{\circ} \mathrm{C}$. Below this temperature, the reaction was kinetically-limited as the reaction rate was not high enough to consume the continuously-fed $\mathrm{ZnO}$ particles. At $900^{\circ} \mathrm{C}$, the actual $\mathrm{ZnO}$ consumption rate was 
roughly half the feeding rate value, thereby explaining that the global reaction duration (Fig. 6) was higher than the feeding period ( $10 \mathrm{~min}$ for $1 \mathrm{~g} / \mathrm{min}$ feeding rate).

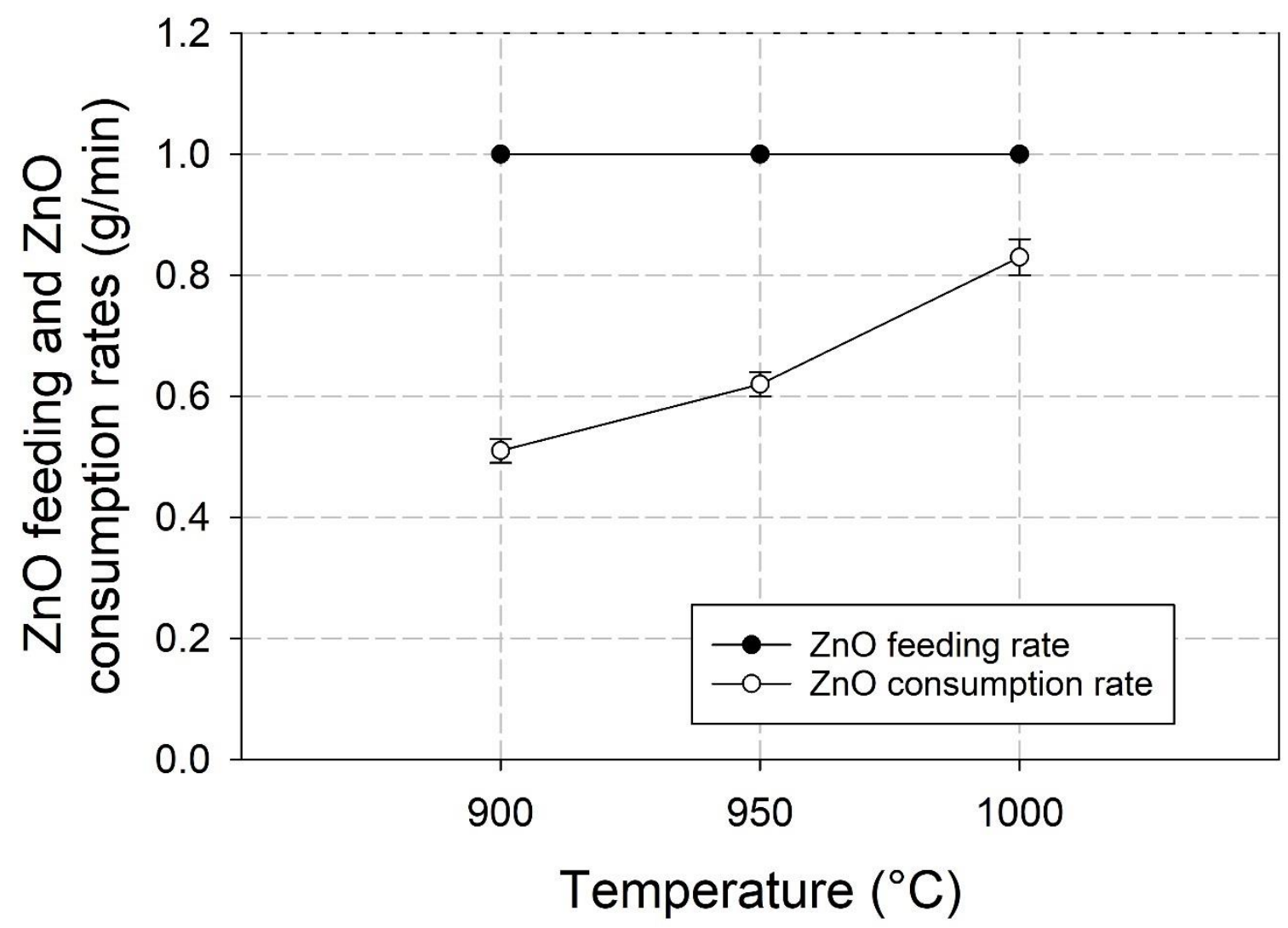

Fig. 8. $\mathrm{ZnO}$ feeding and consumption rates as a function of temperature (for a constant $\mathrm{ZnO}$ feeding rate of $1.0 \mathrm{~g} / \mathrm{min}$ ).

As expected, increasing the temperature substantially improved both methane conversion $\left(X_{C H 4}\right)$ and $\mathrm{ZnO}$ conversion $\left(X_{\mathrm{ZnO}}\right)$, from $5.6 \%$ and $53.1 \%$ at $900{ }^{\circ} \mathrm{C}$ to $14.6 \%$ and $69.1 \%$ at $1000{ }^{\circ} \mathrm{C}$ (Fig. 9a). Nevertheless, presence of $\mathrm{ZnO}$ remaining in the cavity was identified at all temperatures studied here, and it decreased with increasing temperature, according to Fig. S3. It can also be noticed that the reaction temperature of $900^{\circ} \mathrm{C}$ is a lower bound limit to recover solid $\mathrm{Zn}$ product from $\mathrm{Zn}$ vapor condensation at the reactor outlet. Lower temperatures would result in $\mathrm{Zn}$ product remaining in the cavity ( $\mathrm{Zn}$ vaporization and 
in-situ separation from the solid $\mathrm{ZnO}$ is indeed possible above $\mathrm{Zn}$ boiling point $=907^{\circ} \mathrm{C}$ ). Carbon conversion factor $\left(X_{C}\right)$ consistently dropped with temperature, from $99.9 \%\left(900{ }^{\circ} \mathrm{C}\right)$ to $93.4 \%\left(1000{ }^{\circ} \mathrm{C}\right)$, in agreement with the increase of solid carbon formation (Fig. 7). Remarkably, at $900{ }^{\circ} \mathrm{C}, X_{C}$ reached almost $100 \%$ in agreement with negligible carbon formation at this temperature (Fig. 7), confirming the absence of methane cracking reaction. Fig. $9 \mathrm{~b}$ shows that the energy upgrade factor $(U)$ dropped slightly from $1.08\left(900{ }^{\circ} \mathrm{C}\right)$ to 1.04 $\left(1000{ }^{\circ} \mathrm{C}\right)$ due to increased solid carbon formation (Fig. 7). Note that the calorific value of solid carbon was not taken into account to calculate $U$ in Eq. 11, which thus explained a drop in $U$ with temperature.

Solar-to-fuel energy conversion efficiency $\left(\eta_{\text {solar-to-fuel }}\right)$ was in the range $4.5-5.0 \%$ and the maximum value was found at $950{ }^{\circ} \mathrm{C}$ (Fig. 9c), indicating the optimal temperature. This can be explained by the fact that syngas yield was improved at $950{ }^{\circ} \mathrm{C}$, and solar energy consumption at $950{ }^{\circ} \mathrm{C}\left(\dot{Q}_{\text {solar }}=0.80 \mathrm{~kW}\right)$ was lower than at $1000{ }^{\circ} \mathrm{C}\left(\dot{Q}_{\text {solar }}=0.84 \mathrm{~kW}\right)$, leading to the maximum $\eta_{\text {solar-to-fuel }}$ at $950{ }^{\circ} \mathrm{C}$. Besides, a significantly lower solid carbon formation at $950{ }^{\circ} \mathrm{C}$ in comparison with $1000{ }^{\circ} \mathrm{C}$ supported the optimum temperature at 950 ${ }^{\circ} \mathrm{C}$.

In summary, increasing the temperature promoted $\mathrm{ZnO}+\mathrm{CH}_{4}$ reaction, which enhanced syngas yield, $\mathrm{H}_{2}$ and $\mathrm{CO}$ selectivity, $X_{C H 4}, X_{Z n O}$, and $\eta_{\text {solar-to-fuel. }}$ Meanwhile, $\mathrm{C}$ (solid carbon) yield increased with temperature because of favored methane cracking, especially at $1000{ }^{\circ} \mathrm{C}$, contributing to solid carbon formation in the reactor, which in turn decreased $X_{C}$ and $U$. In addition, the temperature increase lowered $\eta_{\text {solar-to-fuel }}$ because of higher solar power consumption. The intermediate temperature at $950{ }^{\circ} \mathrm{C}$ was found to be appropriate for conducting the continuous methane-driven $\mathrm{ZnO}$ reduction thanks to both enhanced reaction extent (with diminished thermal methane dissociation) and maximum $\eta_{\text {solar- }}$ to-fuel. 

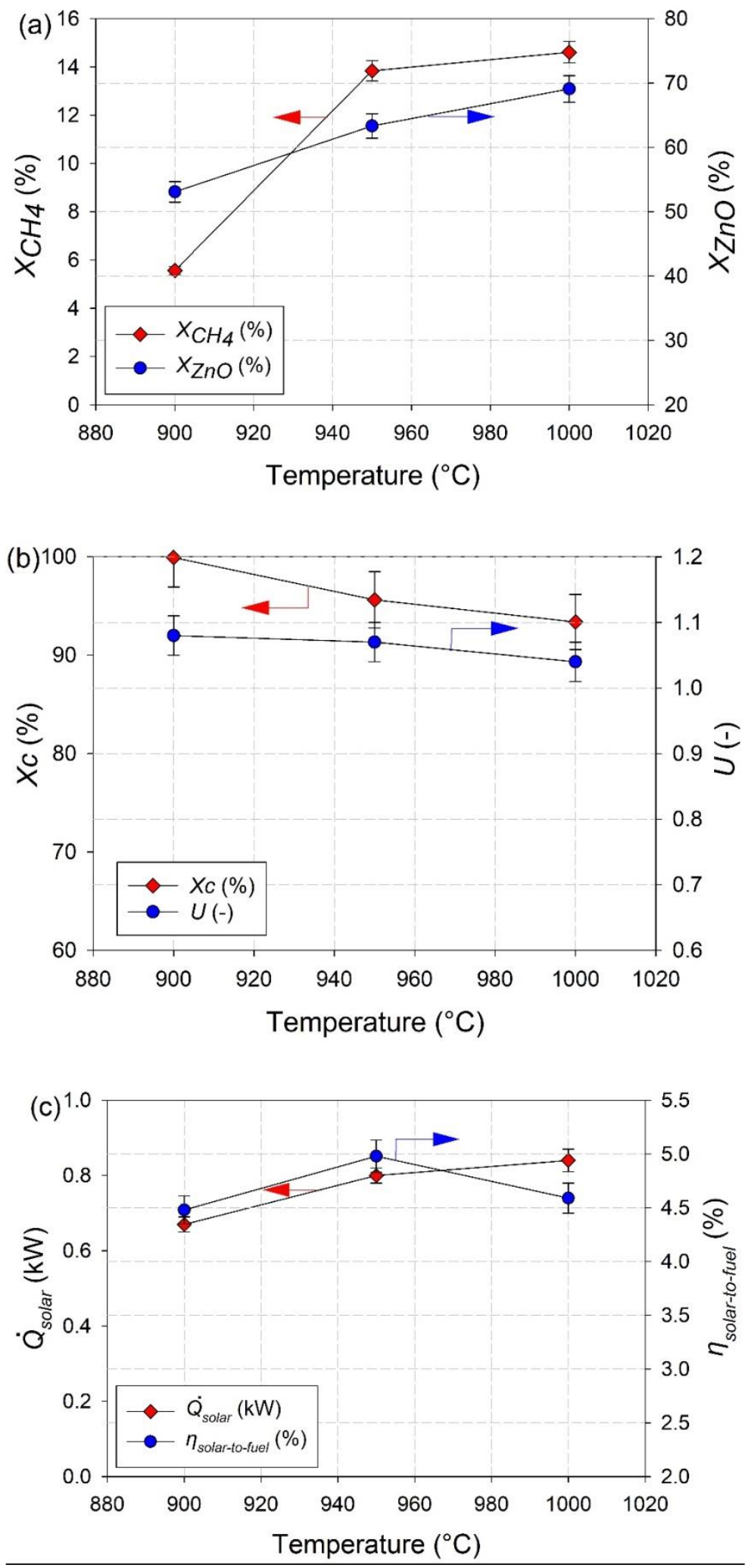
Fig. 9. Impact of temperature on: (a) $\mathrm{CH}_{4}$ conversion $\left(X_{C H 4}\right)$ and $\mathrm{ZnO}$ conversion $\left(X_{\mathrm{ZnO}}\right)$, (b) carbon conversion factor $\left(X_{C}\right)$ and energy upgrade factor $(U)$, and (c) solar power input $\left(\dot{Q}_{\text {solar }}\right)$ and solar-to-fuel energy conversion efficiency $\left(\eta_{\text {solar-to-fuel }}\right)$.

\subsection{Effect of $\mathrm{ZnO}$ feeding rate}

$\mathrm{ZnO}$ feeding rate can play a key role in continuous methane-driven $\mathrm{ZnO}$ reduction. $\mathrm{In}$ this study, $\mathrm{ZnO}$ feeding rate was raised while keeping constant the $\mathrm{CH}_{4} / \mathrm{ZnO}$ ratio $(=1.5)$ at $950{ }^{\circ} \mathrm{C}$ until reaching its optimum point regarding the highest syngas yield and maximum reactor performance. Based on the results of the previous section, the intermediate temperature of $950{ }^{\circ} \mathrm{C}$ was chosen to diminish the side methane cracking reaction. $\mathrm{ZnO}$ powder feeding rate (10 g initial mass) was adjusted at 0.5 (Run\#3), 1.0 (Run\#4), 1.2 (Run\#6), and $1.5 \mathrm{~g} / \mathrm{min}(\mathrm{Run} \# 7)$.

Fig. 10 shows syngas production rates along with reactor temperatures as a function of $\mathrm{ZnO}$ feeding rate. A relatively stable pattern in the evolution of operating temperature confirmed isothermal operation, and a narrow gap between $T_{\text {pyrometer }}$ and $T_{1}$ ensured homogeneous temperatures in the reaction site. A slight variation in the $T_{\text {pyrometer }}$ values indicates the reaction starting to take place when $\mathrm{ZnO}$ is injected. Overall, $\mathrm{ZnO}$ feedstock injection was complete regardless of the feeding rates (highlighting functional feeding system performance), and syngas production rate evolutions were found to be dependent on $\mathrm{ZnO}$ feeding rate. At the initial state, only a small amount of $\mathrm{H}_{2}$ was first generated owing to the thermal dissociation of methane. Subsequently, $\mathrm{H}_{2}, \mathrm{CO}$, and $\mathrm{CO}_{2}$ were produced together after $\mathrm{ZnO}$ reacted with methane, according to Eq. 1. At the lowest $\mathrm{ZnO}$ feeding rate $(0.5$ $\mathrm{g} / \mathrm{min}$ ), the $\mathrm{ZnO}$ reduction started from $10 \mathrm{~min}$ after a short delay because of a progressive transport of the reactive $\mathrm{ZnO}$ powder from the hopper to the reactor cavity receiver. 
According to Fig. 10, the syngas production rates increased considerably with inlet $\mathrm{ZnO}$ feeding rate, indicating enhanced $\mathrm{ZnO}+\mathrm{CH}_{4}$ reaction. For instance, the peak $\mathrm{H}_{2}, \mathrm{CO}$, and $\mathrm{CO}_{2}$ production rates were $7.57,3.44$, and $1.34 \mathrm{~mL} \mathrm{~min}^{-1} \mathrm{~g}^{-1}$ at $0.5 \mathrm{~g} / \mathrm{min}$ compared to 18.45 , 8.76, and $2.10 \mathrm{~mL} \mathrm{~min}^{-1} \mathrm{~g}^{-1}$ at $1.5 \mathrm{~g} / \mathrm{min}$. Likewise, raising the $\mathrm{ZnO}$ feeding rate significantly shortened reaction duration, from $43 \mathrm{~min}(0.5 \mathrm{~g} / \mathrm{min})$ to $29 \mathrm{~min}(1.5 \mathrm{~g} / \mathrm{min})$. Thus, a higher $\mathrm{ZnO}$ feeding rate promoted the $\mathrm{ZnO}$ consumption rate while global solar energy consumption was lowered (thanks to shortened reaction duration). However, the reaction durations at 1.5 $\mathrm{g} / \mathrm{min}$ and $1.2 \mathrm{~g} / \mathrm{min}$ were similar, pointing out an over limitation of the maximum $\mathrm{ZnO}$ consumption rate at this temperature (fixed by the reaction kinetics).
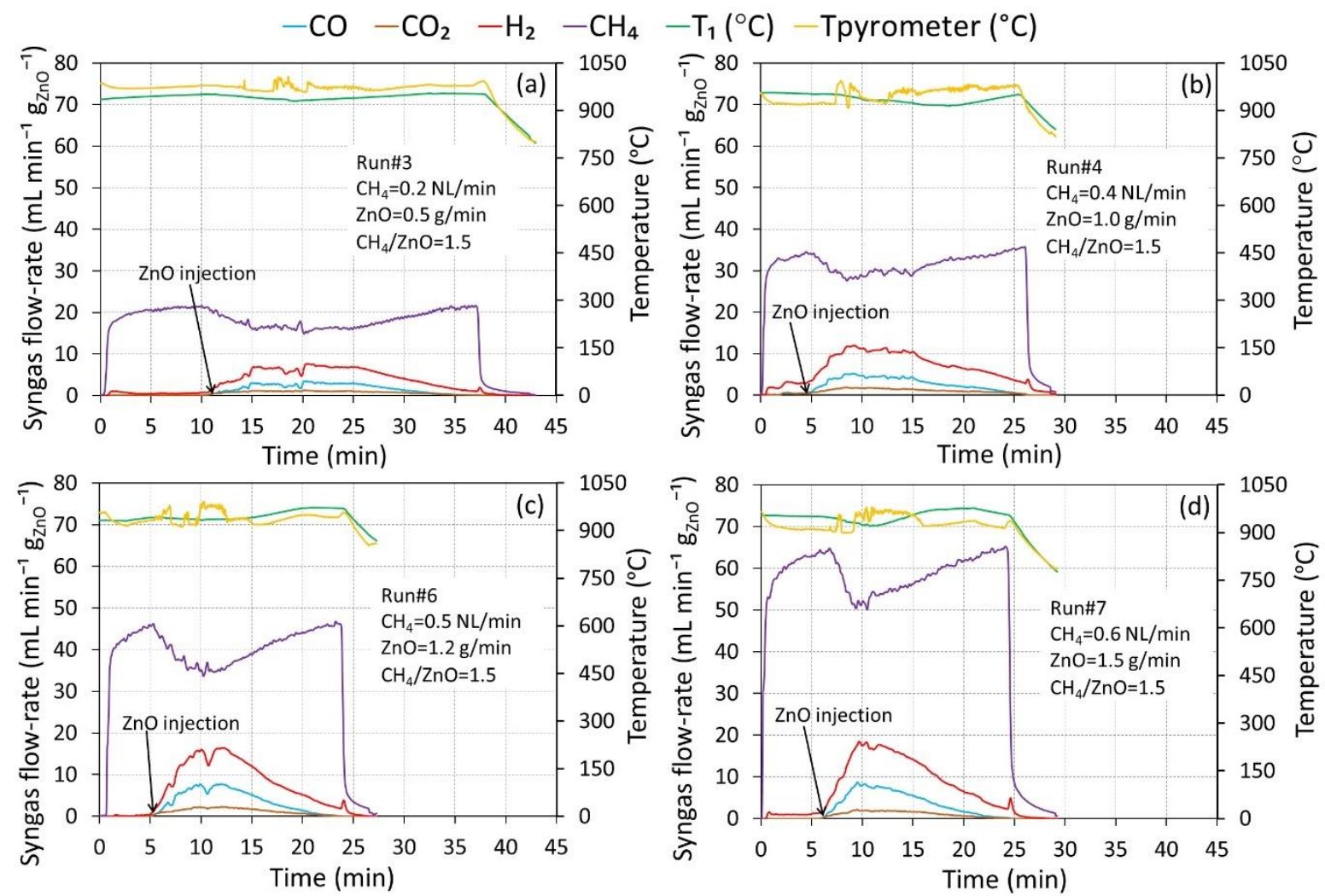

Fig. 10. Evolution of syngas production rates and reactor temperatures ( $T_{1}$ and $\left.T_{\text {pyrometer }}\right)$ during continuous methane-driven $\mathrm{ZnO}$ reduction at inlet $\mathrm{ZnO}$ feeding rates of: (a) $0.5 \mathrm{~g} / \mathrm{min}$, (b) $1.0 \mathrm{~g} / \mathrm{min}$, (c) $1.2 \mathrm{~g} / \mathrm{min}$, and (d) $1.5 \mathrm{~g} / \mathrm{min}$. 
As clearly shown in Fig. 11, an increase in $\mathrm{ZnO}$ feeding rate enhanced syngas yields. $\mathrm{H}_{2}$ and $\mathrm{CO}$ yields rose significantly from 5.95 and $2.09 \mathrm{mmol} / \mathrm{g}_{\mathrm{ZnO}}$ at $0.5 \mathrm{~g} / \mathrm{min}$ to 8.99 and $3.31 \mathrm{mmol} / \mathrm{g}_{\mathrm{ZnO}}$ at $1.5 \mathrm{~g} / \mathrm{min}$ while $\mathrm{CO}_{2}$ yield was in the range of $0.93-1.23 \mathrm{mmol} / \mathrm{g}_{\mathrm{ZnO}}$, resulting in total syngas yield from 8.98 to $13.23 \mathrm{mmol} / \mathrm{g}_{\mathrm{ZnO}}$. This syngas production increase also led to a significant increase in the $\mathrm{H}_{2}$ and $\mathrm{CO}$ selectivity (from 0.76 and 0.69 at $0.5 \mathrm{~g} / \mathrm{min}$ to 0.83 and 0.78 at $1.5 \mathrm{~g} / \mathrm{min}$, respectively). The $\mathrm{C}$ yield remained quite stable in the range 0.83-1.02 $\mathrm{mmol} / \mathrm{g}_{\mathrm{ZnO}}$ for $\mathrm{ZnO}$ feeding rates between $0.5-1.2 \mathrm{~g} / \mathrm{min}$. When increasing further $\mathrm{ZnO}$ feeding rate to $1.5 \mathrm{~g} / \mathrm{min}$, a significant rise in $\mathrm{C}$ formation $\left(1.37 \mathrm{mmol} / \mathrm{g}_{\mathrm{ZnO}}\right)$ was noticed. In addition, the reaction duration at $1.5 \mathrm{~g} / \mathrm{min}$ was unchanged compared to $1.2 \mathrm{~g} / \mathrm{min}$ (Fig. 10), thus implying an over-limit of the $\mathrm{ZnO}$ feeding rate.

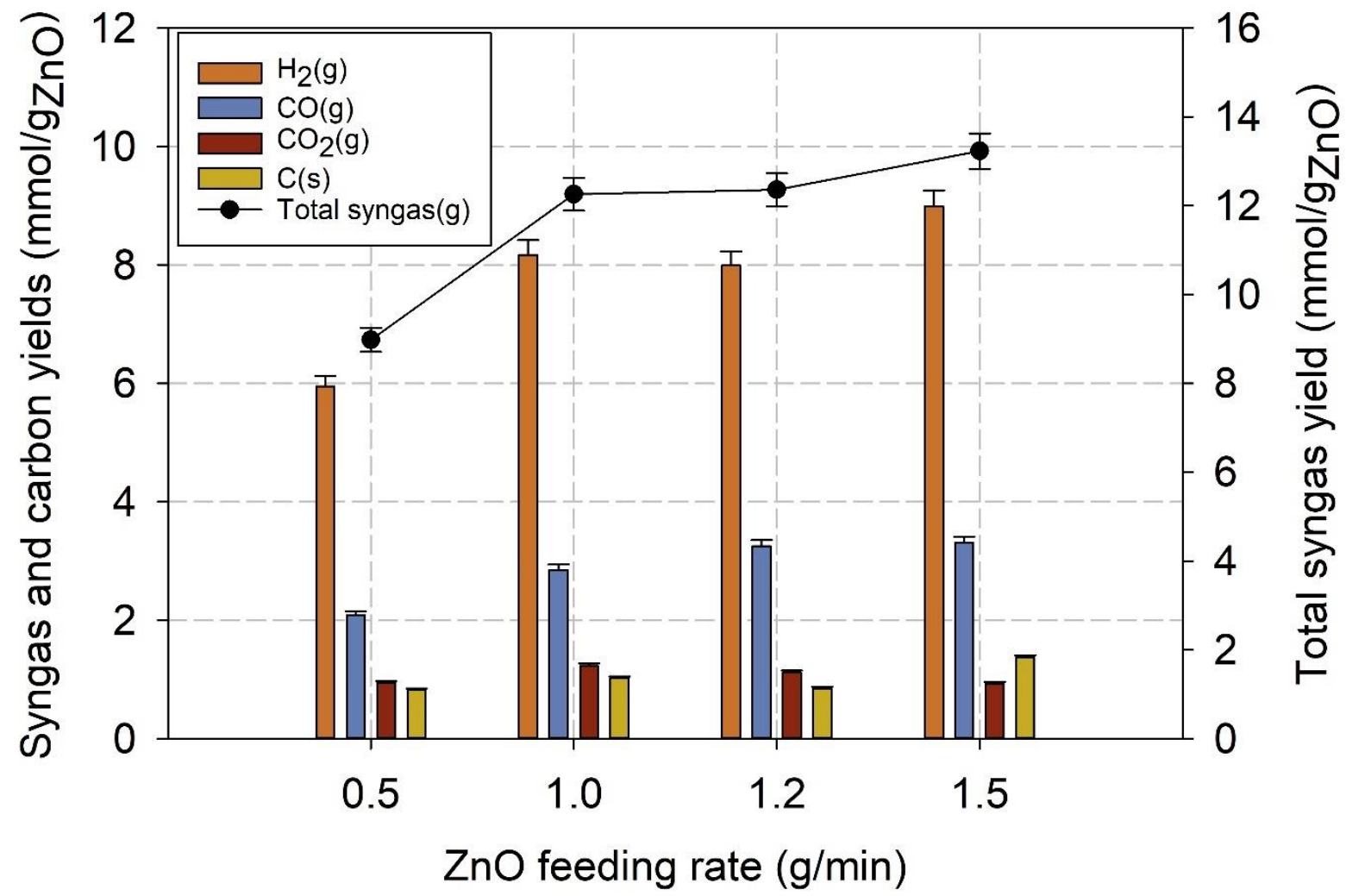


Fig. 11. Syngas yields as a function of $\mathrm{ZnO}$ feeding rate at $950{ }^{\circ} \mathrm{C}\left(\mathrm{CH}_{4} / \mathrm{ZnO}=1.5\right)$.

Fig. 12 displays the actual $\mathrm{ZnO}$ consumption rate compared with the ideal $\mathrm{ZnO}$ consumption rate plotted as a function of $\mathrm{ZnO}$ feeding rate. With increasing $\mathrm{ZnO}$ feeding rate, the actual $\mathrm{ZnO}$ consumption rate increased, which points out the improvement of $\mathrm{ZnO}+\mathrm{CH}_{4}$ reaction, and then reached the maximum value of $0.83 \mathrm{~g} / \mathrm{min}$ at $\mathrm{ZnO}$ feeding rate $=$ $1.2 \mathrm{~g} / \mathrm{min}$. It finally decreased after reaching the maximum point due to the over limitation of $\mathrm{ZnO}$ feeding rate. However, the actual oxygen consumption rate was always below the ideal line, meaning that $\mathrm{ZnO}$ consumption rate was significantly lower than $\mathrm{ZnO}$ feeding rate, which resulted in temporal $\mathrm{ZnO}$ accumulation. These results are in agreement with incomplete $\mathrm{ZnO}$ conversion $\left(X_{\mathrm{ZnO} O}\right)$, as shown in Fig. 13a.

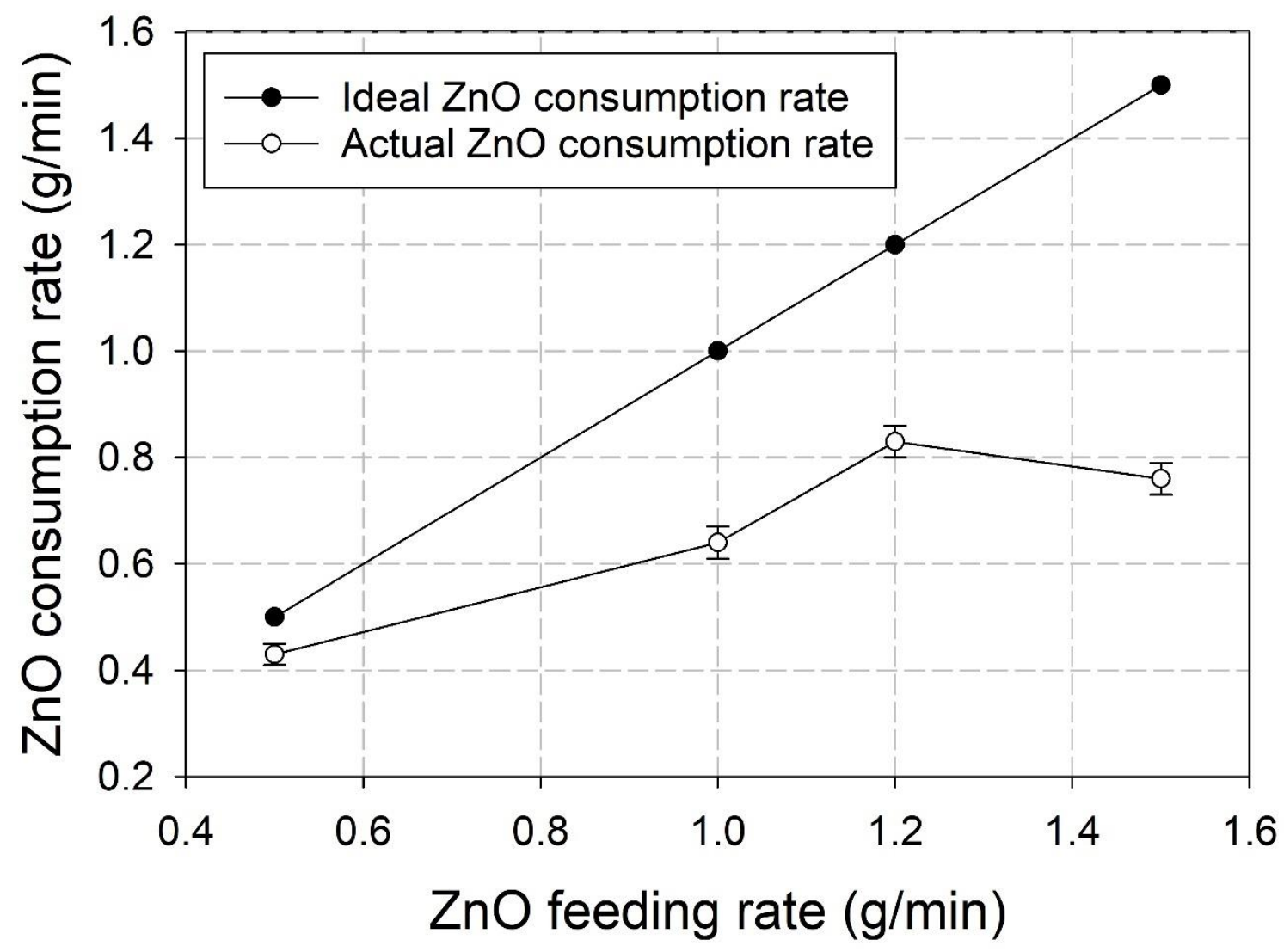


Fig. 12. Effect of $\mathrm{ZnO}$ feeding rate on $\mathrm{ZnO}$ consumption rate.

Fig. 13 confirms that an optimal $\mathrm{ZnO}$ feeding rate of $1.2 \mathrm{~g} / \mathrm{min}$ can be identified with respect to both the maximum values of $X_{Z n O}(63.0 \%)$ and $\eta_{\text {solar-to-fuel }}(5.3 \%)$. In agreement with the syngas yield tendency (Fig. 11), $X_{\mathrm{ZnO}}$ and $X_{\mathrm{CH} 4}$ increased with $\mathrm{ZnO}$ feeding rate, and subsequently, they dropped significantly after their optimal point. $X_{C H 4}$ was found in the range $8.0-13.8 \%$ with its minimum value found at $1.5 \mathrm{~g} / \mathrm{min}$, confirming an over limitation of the inlet reactants flow rate (Fig. 13a). $U$ exceeded one (1.06-1.13) within the considered range (Fig. 13b), demonstrating successful solar energy storage in chemical products. $U$ decreased slightly with $\mathrm{ZnO}$ feeding rate because of increased solid carbon formation (Fig. 11), which led to $X_{C}$ in the range $95.6-98.3 \%$. Actually, at this temperature $\left(950{ }^{\circ} \mathrm{C}\right)$, the side methane cracking reaction was not favorable, as evidenced by the low $\mathrm{C}$ yield and almost complete $X_{C}$. Although solar power was increasingly consumed $\left(\dot{Q}_{\text {solar }}=0.78-0.81 \mathrm{~kW}\right)$, $\eta_{\text {solar-to-fuel }}$ still rose with $\mathrm{ZnO}$ feeding rate (Fig. 13c) and reached the highest value of $5.3 \%$ at $1.2 \mathrm{~g} / \mathrm{min}$. It then leveled off at $1.5 \mathrm{~g} / \mathrm{min}$. The improved $\eta_{\text {solar-to-fuel }}$ was due to both the enhanced syngas yield (Fig. 11) and the reduction of solar energy consumption (shortened reaction duration, as observed in Fig. 10).

In summary, increasing the $\mathrm{ZnO}$ feeding rate under a constant $\mathrm{ZnO} / \mathrm{CH}_{4}$ molar ratio significantly enhanced continuous syngas production from $\mathrm{ZnO}+\mathrm{CH}_{4}$ reaction and solar reactor performance. Indeed, significant benefits were evidenced based on the enhanced syngas production rate, syngas yield, $X_{C H 4}, X_{Z n O}, \eta_{\text {solar-to-fuel }}$, and improved $\mathrm{ZnO}$ consumption rate (evidenced by shortened duration). However, over-limitation of $\mathrm{ZnO}$ feeding rate diminished the syngas yield and reactor performance due to $\mathrm{ZnO}$ feeding rate becoming higher than $\mathrm{ZnO}$ consumption rate, possibly leading to $\mathrm{ZnO}$ accumulation in the reactor. Therefore, the $\mathrm{ZnO}$ feeding rate must well fit the $\mathrm{ZnO}$ consumption rate to maximize the gas 
yield and reactor performance at each temperature. With respect to the achieved performance, the optimal $\mathrm{ZnO}$ feeding rate at $950{ }^{\circ} \mathrm{C}$ was found to be $1.2 \mathrm{~g} / \mathrm{min}$. The existence of a tradeoff in feedstock feeding rate during methane-driven $\mathrm{ZnO}$ reduction is a key aspect for the reliable continuous operation of scaled-up solar reactors. 

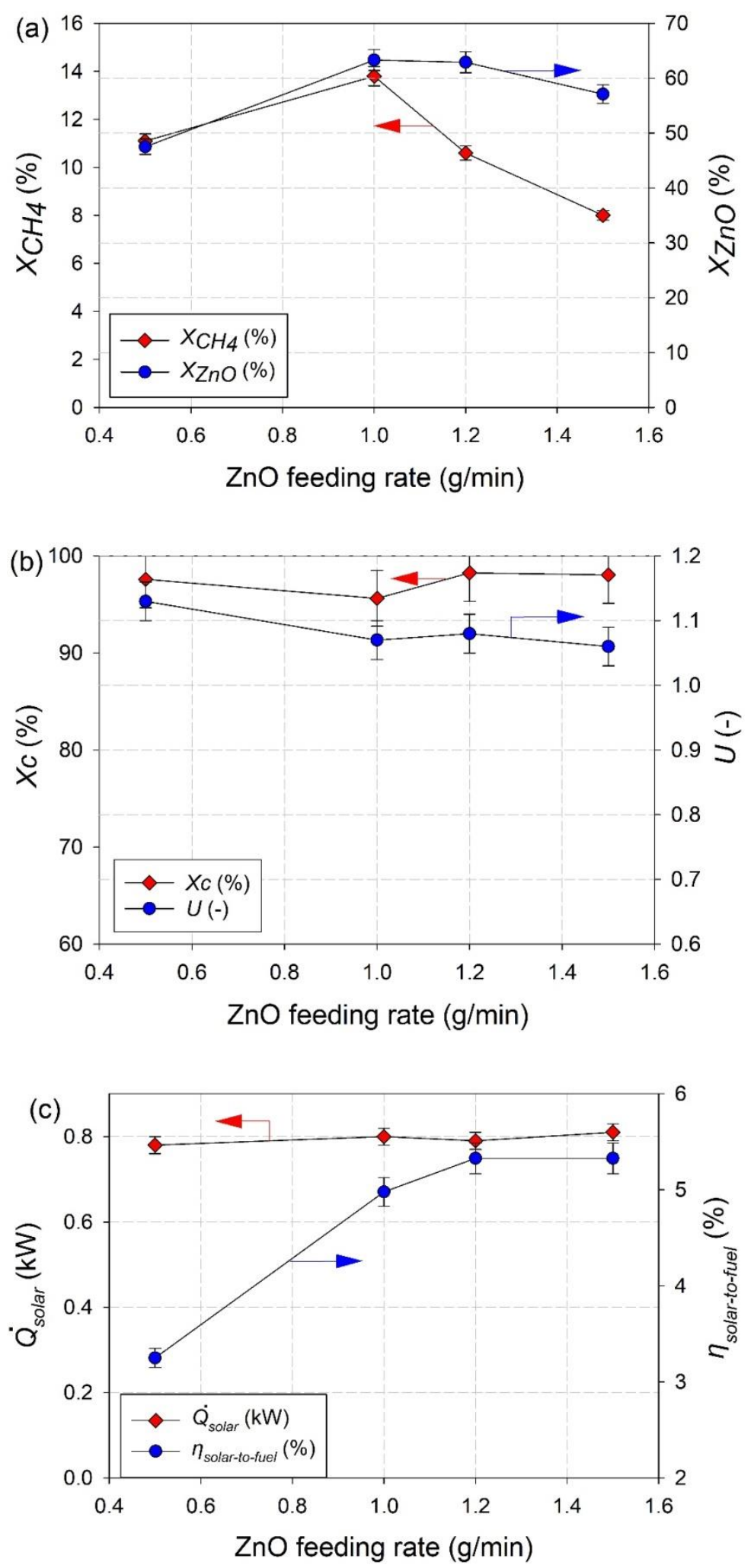

Fig. 13. Influence of $\mathrm{ZnO}$ feeding rate at $950{ }^{\circ} \mathrm{C}$ on (a) $\mathrm{ZnO}$ conversion $\left(X_{\mathrm{ZnO}}\right)$ and $\mathrm{CH}_{4}$ conversion $\left(X_{C H 4}\right)$, (b) carbon conversion $\left(X_{C}\right)$ and energy upgrade factor $(U)$, and (c) solar power input $\left(\dot{Q}_{\text {solar }}\right)$ and solar-to-chemical energy conversion efficiency ( $\left.\eta_{\text {solar-to-fuel }}\right)$. 


\section{6 $\mathrm{Zn}$ product characterization}

According to Fig. 1, solid products collected from the outlet alumina tube plus 90degree connector (represented as zone A) and the ceramic filter (represented as zone B) were separately quantified using a digital weighing balance with a precision scale of $0.01 \mathrm{mg}$. Subsequently, they were analyzed using XRD to determine their crystallographic structure and FESEM to observe their crystal microstructure and morphology. According to Table S2 (Supplementary Material), the solid products (a mixture of $\mathrm{Zn}$ and soot, Fig. S6) condensed mainly at zone A (in the range 3.85-10.22 g), followed by zone B (in the range 1.63-4.82 g), resulting in the total solid mass of 5.96-15.04 g. In comparison, the total amount of solid product was slightly lower than the theoretically expected amount of $\mathrm{Zn}$ by $10-20 \%$ (Table S2) due to incomplete $\mathrm{ZnO}$ conversion, as evidenced by some $\mathrm{ZnO}$ remaining in the reactor cavity receiver (Fig. S3).

$\mathrm{Zn}$ purity in the collected powder was determined. Pure $\mathrm{Zn}$ production was achieved as the recovered solid product at reactor outlet mainly contained metallic Zn. Fig. 14 shows the XRD patterns of solid products from both zone A and zone B for temperatures of 900, 950, and $1000{ }^{\circ} \mathrm{C}$ (corresponding to the results shown in Fig. 6) and compared with the reference XRD pattern of pure $\mathrm{Zn}$. Overall, the $\mathrm{Zn}$ patterns with prominent and high peak intensity were clearly identified for both zones, demonstrating high-purity $\mathrm{Zn}$ production. The mean crystallite size of the solid Zn product was determined from Scherrer's equation and found in the range of 52-95 $\mathrm{nm}$ for zone A, and 22-74 $\mathrm{nm}$ for zone B.

The impact of operating temperature on Zn purity was insignificant. At zone A (Fig. 14a), traces of $\mathrm{ZnO}$ with characteristic peaks were observed especially at the highest temperature. It was attributed to the $\mathrm{Zn}$ recombination with $\mathrm{CO}, \mathrm{CO}_{2}$, or $\mathrm{H}_{2} \mathrm{O}$ (favorable reactions according to thermodynamics, Fig. S4) during gas cooling when flowing at the 
reactor outlet, which additionally supported the incomplete $X_{Z n O}$. Conversely, only the pure $\mathrm{Zn}$ pattern was clearly found at zone B (Fig. 14b), implying negligible $\mathrm{Zn}$ recombination in the outlet gas flow and high-purity Zn production.

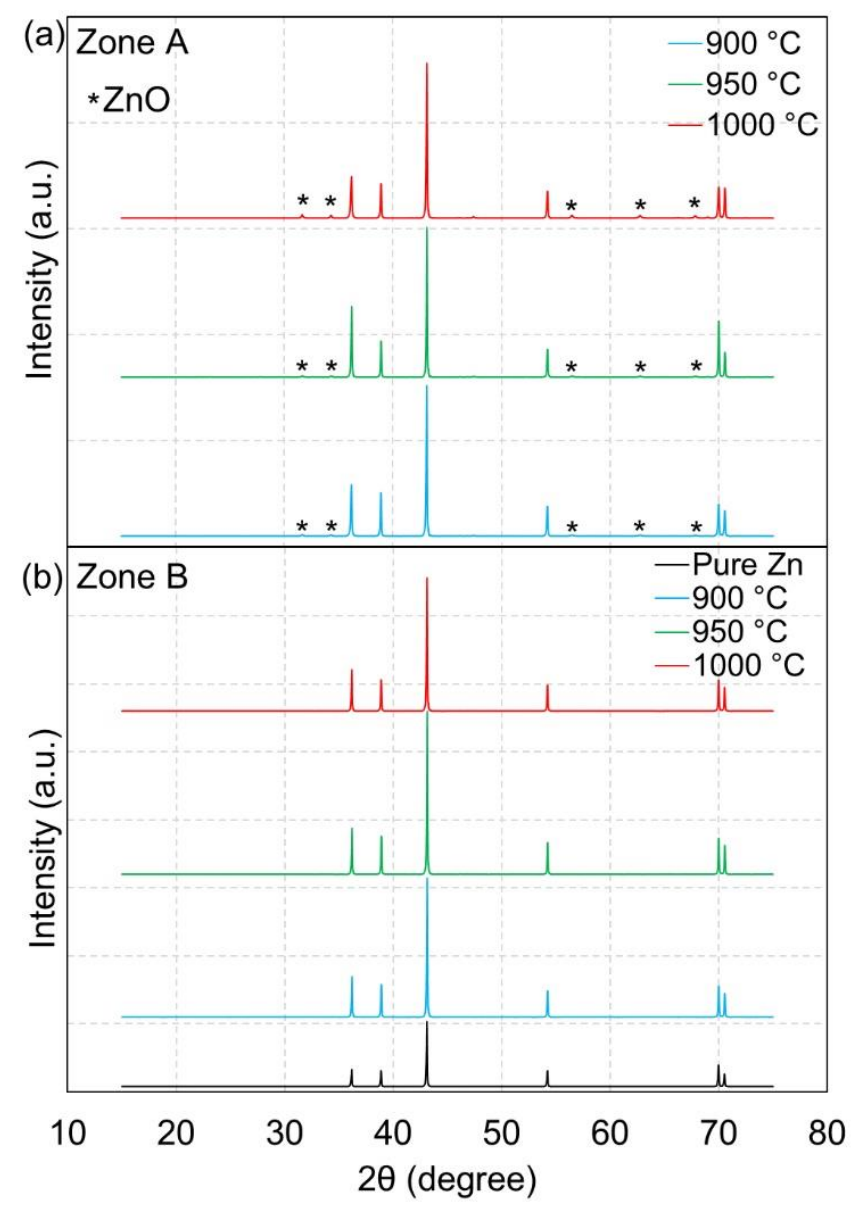

Fig. 14. XRD patterns of the collected solid Zn products deposited in the outlet alumina tube and connector (zone A) and ceramic filter (zone B) for temperatures of 900, 950, and 1000 ${ }^{\circ} \mathrm{C}$.

Fig. 15 displays the XRD patterns of the solid $\mathrm{Zn}$ products for $\mathrm{ZnO}$ feeding rates of 0.5, 1.0, 1.2, and $1.5 \mathrm{~g} / \mathrm{min}$ at $950{ }^{\circ} \mathrm{C}$ (corresponding to the results shown in Fig. 10), compared to a XRD pattern of pure Zn. Remarkably, only the Zn crystalline phase was identified in both 
zones, revealing an effective process for continuous pure $\mathrm{Zn}$ production, without any influence of $\mathrm{ZnO}$ feeding rate on $\mathrm{Zn}$ purity.

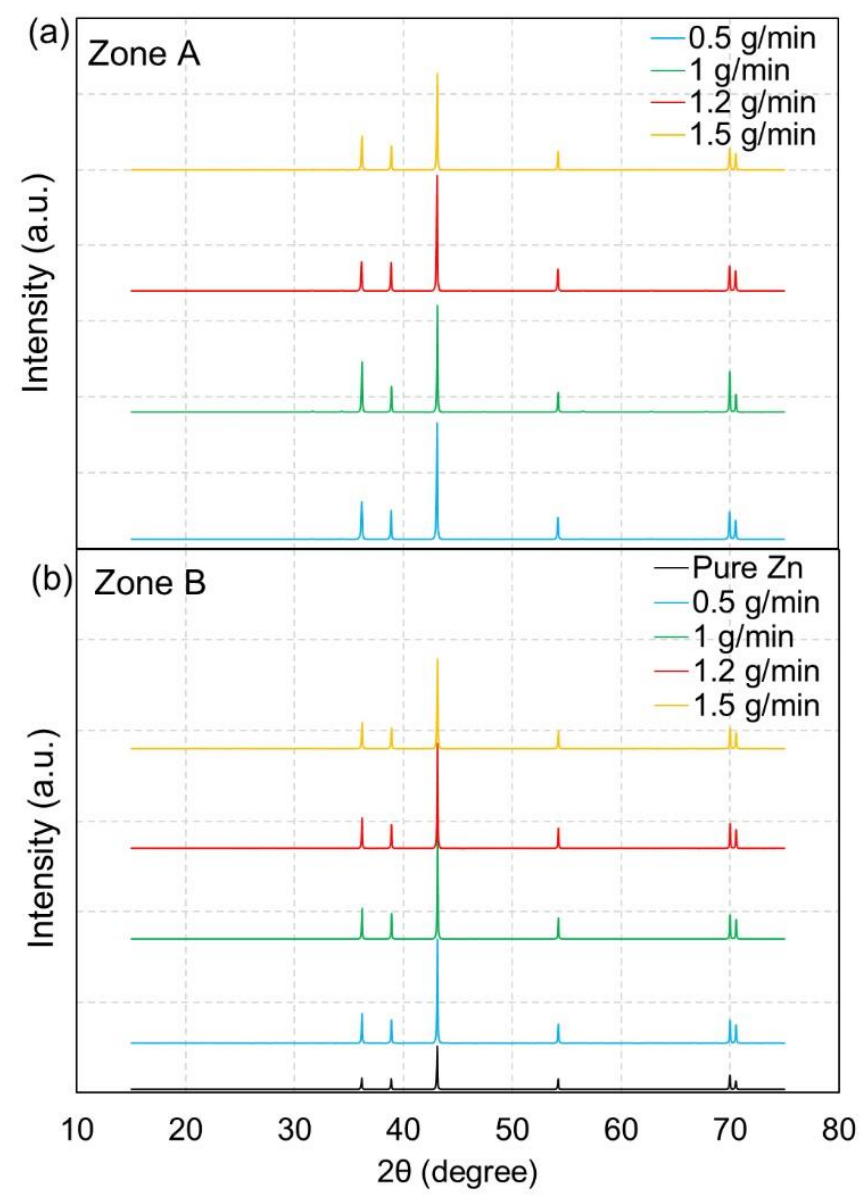

Fig. 15. XRD patterns of the collected solid Zn products deposited in the outlet alumina tube and connector (zone A) and ceramic filter (zone B) for $\mathrm{ZnO}$ feeding rates of 0.5, 1.0, 1.2, and

$$
1.5 \mathrm{~g} / \mathrm{min} \text { at } 950{ }^{\circ} \mathrm{C} \text {. }
$$

FESEM micrographs of the solid products collected in Run\#1 are presented in Fig. 16. For both regions, the particle size, morphology, and surface topography of the produced $\mathrm{Zn}$ can be visually observed. $\mathrm{Zn}$ particle size was found approximately in the range 0.1-1.2 $\mu \mathrm{m}$. At zone A, produced $\mathrm{Zn}$ grew in plane layers with a hexagonal crystal shape. This was because at this zone $\mathrm{Zn}$ vapor condensed in contact with the cooled inner wall surface of the outlet tube. At zone B, Zn particles were found to be hexagonal or spherical with plane facets 
(suggesting condensation as droplets), scattered over the surface area, with average particle sizes above $400 \mathrm{~nm}$.

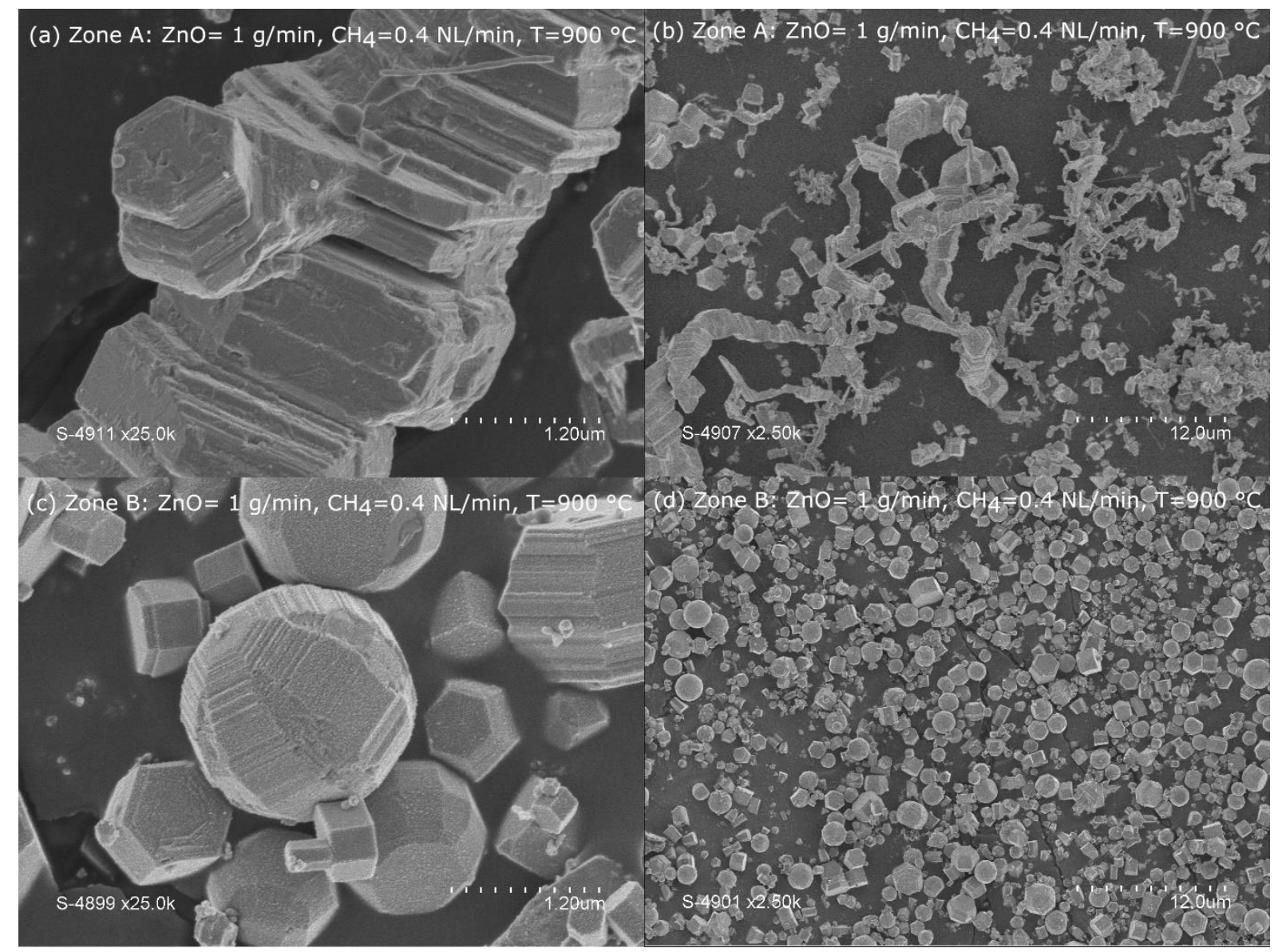

Fig. 16. FESEM images of the solid products collected in $(a, b)$ outlet alumina tube and connector (zone A) and (c,d) ceramic filter at a $\mathrm{ZnO}$ feeding rate of $1 \mathrm{~g} / \mathrm{min}, \mathrm{CH}_{4}$ feeding rate of $0.4 \mathrm{NL} / \mathrm{min}$, and temperature of $900{ }^{\circ} \mathrm{C}$ (Run\#1).

\section{Conclusions}

Experimental demonstration of continuous methane-driven $\mathrm{ZnO}$ reduction in a prototype solar chemical reactor has been successfully performed. The considered process is 
equivalent to methane reforming with solid $\mathrm{ZnO}$, and is an alternative to conventional steam and dry reforming processes. The solar process combines $\mathrm{ZnO}$ reduction with methane reforming to generate both pure zinc and hydrogen-rich syngas. New insights were provided on the solar reactor design for continuous processing with $\mathrm{Zn}$ particle generation and extraction from the reactor, and experimental tests were carried out for reaction scheme investigation and continuous operation demonstration. The influence of $\mathrm{CH}_{4} / \mathrm{ZnO}$ molar ratio (1-1.5) and temperature $\left(900-1000{ }^{\circ} \mathrm{C}\right)$ on syngas production rates, yields, and reactor performance $\left(X_{\mathrm{ZnO}}, X_{\mathrm{CH} 4}, U\right.$, and $\left.\eta_{\text {solar-to-fuel }}\right)$ was first evaluated. Then, the influence of $\mathrm{ZnO}$ feeding rate $(0.2-1.5 \mathrm{~g} / \mathrm{min})$ was investigated, and the existence of an optimal feeding point was emphasized. The highest temperature at $1000{ }^{\circ} \mathrm{C}$ exhibited the maximum syngas yield (15.20 $\left(\mathrm{H}_{2}\right), 3.47(\mathrm{CO})$, and $\left.1.26\left(\mathrm{CO}_{2}\right) \mathrm{mmol} / \mathrm{g}_{\mathrm{ZnO}}\right), X_{\mathrm{ZnO}}(69.08 \%)$, and $X_{\mathrm{CH} 4}(14.61 \%)$ at the expense of pronounced side methane cracking reaction, thus resulting in the maximum solid carbon formation $\left(3.91 \mathrm{mmol} / \mathrm{g}_{\mathrm{ZnO}}\right)$. The excess methane $\left(\mathrm{CH}_{4} / \mathrm{ZnO}=1.5\right)$ and the intermediate temperature at $950{ }^{\circ} \mathrm{C}$ were suitable conditions to improve the continuous $\mathrm{ZnO}+\mathrm{CH}_{4}$ reaction while alleviating methane cracking reaction.

An increase in the $\mathrm{ZnO}$ feeding rate (under a constant $\mathrm{ZnO} / \mathrm{CH}_{4}$ molar ratio) significantly promoted syngas production rates, yields, and reactor performance thanks to increased $\mathrm{ZnO}$ consumption rate (reflected by diminished reaction duration). However, excessively high $\mathrm{ZnO}$ feeding rate led to temporal $\mathrm{ZnO}$ accumulation in the reactor due to $\mathrm{ZnO}$ feeding rate exceeding $\mathrm{ZnO}$ consumption rate. The optimal $\mathrm{ZnO}$ feeding rate at $950{ }^{\circ} \mathrm{C}$ with respect to both the highest $X_{Z n O}(62.9 \%)$ and $X_{C H 4}(10.6 \%)$ was found at $1.2 \mathrm{~g} / \mathrm{min}$ for performing on-sun continuous methane-driven $\mathrm{ZnO}$ reduction.

High-purity $\mathrm{Zn}$ was produced in the form of deposits in plane layers at the outlet tube and micron-size particles (with hexagonal crystal shape) at the ceramic filter. Demonstration of continuous solar methane-driven $\mathrm{ZnO}$ reduction provided insights into the process 
feasibility and reliability, which can be useful in scale-up development. The considered solar process is suitable to convert methane to syngas while simultaneously producing $\mathrm{Zn}$ in a single process. It is thus a novel renewable option for both sustainable fuel production and solar-driven extractive metallurgy.

\section{Acknowledgments}

This work was performed under an academic joint project between King Mongkut's Institute of Technology Ladkrabang, KMITL (grant number: KREF046404) and PROMES-CNRS. R. Garcia is gratefully acknowledged for solar reactor technical support.

\section{References}

[1] S. Rodat, S. Abanades, H. Boujjat, S. Chuayboon, On the path toward day and night continuous solar high temperature thermochemical processes: A review, Renew. Sustain. Energy Rev. 132 (2020) 110061. doi:https://doi.org/10.1016/j.rser.2020.110061.

[2] C. Falter, A. Valente, A. Habersetzer, D. Iribarren, J. Dufour, An integrated technoeconomic, environmental and social assessment of the solar thermochemical fuel pathway, Sustain. Energy Fuels. 4 (2020) 3992-4002. doi:10.1039/D0SE00179A.

[3] S. Chuayboon, S. Abanades, An overview of solar decarbonization processes, reacting oxide materials, and thermochemical reactors for hydrogen and syngas production, Int. J. Hydrogen Energy. 45 (2020) 25783-25810. doi:https://doi.org/10.1016/j.ijhydene.2020.04.098.

[4] H. Boujjat, S. Rodat, S. Chuayboon, S. Abanades, Experimental and CFD investigation of inert bed materials effects in a high-temperature conical cavity-type 
reactor for continuous solar-driven steam gasification of biomass, Chem. Eng. Sci. 228 (2020) 115970. doi:https://doi.org/10.1016/j.ces.2020.115970.

[5] S. Chuayboon, S. Abanades, S. Rodat, Solar chemical looping gasification of biomass with the $\mathrm{ZnO} / \mathrm{Zn}$ redox system for syngas and zinc production in a continuously-fed solar reactor, Fuel. 215 (2018) 66-79. doi:10.1016/j.fuel.2017.11.021.

[6] S. Chuayboon, S. Abanades, Clean magnesium production using concentrated solar heat in a high-temperature cavity-type thermochemical reactor, J. Clean. Prod. 232 (2019) 784-795. doi:10.1016/j.jclepro.2019.05.371.

[7] S. Abanades, A. Haeussler, A. Julbe, Thermochemical solar-driven reduction of $\mathrm{CO}_{2}$ into separate streams of $\mathrm{CO}$ and $\mathrm{O}_{2}$ via an isothermal oxygen-conducting ceria membrane reactor, Chem. Eng. J. 422 (2021) 130026. doi:https://doi.org/10.1016/j.cej.2021.130026.

[8] S. Chuayboon, S. Abanades, S. Rodat, Stepwise Solar Methane Reforming and WaterSplitting via Lattice Oxygen Transfer in Iron and Cerium Oxides, Energy Technol. 8 (2019) 1900415. doi:10.1002/ente.201900415.

[9] S. Chuayboon, S. Abanades, Solar-Driven Chemical Looping Methane Reforming Using ZnO Oxygen Carrier for Syngas and Zn Production in a Cavity-Type Solar Reactor, Catalysts. 10 (2020) 1356. doi:10.3390/catal10111356.

[10] S. Chuayboon, S. Abanades, S. Rodat, High-Purity and Clean Syngas and Hydrogen Production From Two-Step $\mathrm{CH}_{4}$ Reforming and $\mathrm{H}_{2} \mathrm{O}$ Splitting Through Isothermal Ceria Redox Cycle Using Concentrated Sunlight, Front. Energy Res. 8 (2020) 128. doi:10.3389/fenrg.2020.00128.

[11] S. Chuayboon, S. Abanades, S. Rodat, Solar chemical looping reforming of methane combined with isothermal $\mathrm{H}_{2} \mathrm{O} / \mathrm{CO}_{2}$ splitting using ceria oxygen carrier for syngas production, J. Energy Chem. 41 (2020) 60-72. 
doi:https://doi.org/10.1016/j.jechem.2019.05.004.

[12] F.A. Costa Oliveira, M.A. Barreiros, A. Haeussler, A.P.F. Caetano, A.I. Mouquinho, P.M. e Silva, R.M. Novais, R.C. Pullar, S. Abanades, High performance corktemplated ceria for solar thermochemical hydrogen production via two-step watersplitting cycles, Sustain. Energy Fuels. 4 (2020) 3077-3089. doi:10.1039/D0SE00318B.

[13] T. Kodama, T. Shimizu, T. Satoh, M. Nakata, K.-I. Shimizu, Stepwise production of CO-rich syngas and hydrogen via solar methane reforming by using a $\mathrm{Ni}(\mathrm{II})$-ferrite redox system, Sol. Energy. 73 (2002) 363-374. doi:https://doi.org/10.1016/S0038092X(02)00112-3.

[14] C. Huang, J. Wu, Y.-T. Chen, M. Tian, A.I. Rykov, B. Hou, J. Lin, C.-R. Chang, X. Pan, J. Wang, A. Wang, X. Wang, In situ encapsulation of iron(0) for solar thermochemical syngas production over iron-based perovskite material, Commun. Chem. 1 (2018) 55. doi:10.1038/s42004-018-0050-y.

[15] M.M. Nair, S. Abanades, Experimental screening of perovskite oxides as efficient redox materials for solar thermochemical $\mathrm{CO}_{2}$ conversion, Sustain. Energy Fuels. 2 (2018) 843-854. doi:10.1039/C7SE00516D.

[16] M.E. Gálvez, A. Frei, G. Albisetti, G. Lunardi, A. Steinfeld, Solar hydrogen production via a two-step thermochemical process based on $\mathrm{MgO} / \mathrm{Mg}$ redox reactions-Thermodynamic and kinetic analyses, Int. J. Hydrogen Energy. 33 (2008) 2880-2890. doi:https://doi.org/10.1016/j.ijhydene.2008.04.007.

[17] L. Xiao, S.-Y. Wu, Y.-R. Li, Advances in solar hydrogen production via two-step water-splitting thermochemical cycles based on metal redox reactions, Renew. Energy. 41 (2012) 1-12. doi:http://dx.doi.org/10.1016/j.renene.2011.11.023.

[18] J.P. Murray, A. Steinfeld, E.A. Fletcher, Metals, nitrides, and carbides via solar 
carbothermal reduction of metal oxides, Energy. 20 (1995) 695-704.

doi:http://dx.doi.org/10.1016/0360-5442(95)00032-C.

[19] G. Levêque, S. Abanades, Investigation of thermal and carbothermal reduction of volatile oxides $\left(\mathrm{ZnO}, \mathrm{SnO}_{2}, \mathrm{GeO}_{2}\right.$, and $\left.\mathrm{MgO}\right)$ via solar-driven vacuum thermogravimetry for thermochemical production of solar fuels, Thermochim. Acta. 605 (2015) 86-94. doi:10.1016/j.tca.2015.02.015.

[20] E.E. Koepf, S.G. Advani, A.K. Prasad, A. Steinfeld, Eeperimental investigation of the carbothermal reduction of $\mathrm{ZnO}$ using a beam-down, gravity-fed solar reactor, Ind. Eng. Chem. Res. (2015) 8319-8332.

[21] K. Otsuka, T. Ushiyama, I. Yamanaka, Partial Oxidation of Methane Using the Redox of Cerium Oxide, Chem. Lett. 22 (1993) 1517-1520. doi:10.1246/cl.1993.1517.

[22] K. Otsuka, M. Hatano, A. Morikawa, Hydrogen from water by reduced cerium oxide, J. Catal. 79 (1983) 493-496. doi:https://doi.org/10.1016/0021-9517(83)90346-9.

[23] K. Li, H. Wang, Y. Wei, D. Yan, Direct conversion of methane to synthesis gas using lattice oxygen of $\mathrm{CeO}_{2}-\mathrm{Fe}_{2} \mathrm{O}_{3}$ complex oxides, Chem. Eng. J. 156 (2010) 512-518. doi:https://doi.org/10.1016/j.cej.2009.04.038.

[24] M. Halmann, A. Frei, A. Steinfeld, Thermo-neutral production of metals and hydrogen or methanol by the combined reduction of the oxides of zinc or iron with partial oxidation of hydrocarbons, Energy. 27 (2002) 1069-1084. doi:https://doi.org/10.1016/S0360-5442(02)00080-4.

[25] H. I. Villafán-Vidales, S. Abanades, M. Montiel-González, H. Romero-Paredes-Rubio, Carbo- and Methanothermal Reduction of Tungsten Trioxide into Metallic Tungsten for Thermochemical Production of Solar Fuels, Energy Technol. 5 (2016) 692-702. doi:10.1002/ente.201600455.

[26] H. Ale Ebrahim, E. Jamshidi, Synthesis gas production by zinc oxide reaction with 
methane: elimination of greenhouse gas emission from a metallurgical plant, Energy Convers. Manag. 45 (2004) 345-363. doi:https://doi.org/10.1016/S01968904(03)00157-2.

[27] S. Abanades, P. Charvin, G. Flamant, P. Neveu, Screening of water-splitting thermochemical cycles potentially attractive for hydrogen production by concentrated solar energy, Energy. 31 (2006) 2805-2822. doi:https://doi.org/10.1016/j.energy.2005.11.002.

[28] P. Haueter, S. Moeller, R. Palumbo, A. Steinfeld, The production of zinc by thermal dissociation of zinc oxide — solar chemical reactor design, Sol. Energy. 67 (1999) 161167. doi:https://doi.org/10.1016/S0038-092X(00)00037-2.

[29] S. Abanades, Thermogravimetry Analysis of $\mathrm{CO}_{2}$ and $\mathrm{H}_{2} \mathrm{O}$ Reduction from Solar Nanosized Zn Powder for Thermochemical Fuel Production, Ind. Eng. Chem. Res. 51 (2012) 741-750. doi:10.1021/ie202518k.

[30] S. Abanades, P. Charvin, G. Flamant, Design and simulation of a solar chemical reactor for the thermal reduction of metal oxides: Case study of zinc oxide dissociation, Chem. Eng. Sci. 62 (2007) 6323-6333. doi:http://dx.doi.org/10.1016/j.ces.2007.07.042.

[31] S. Abanades, G. Flamant, Thermochemical hydrogen production from a two-step solar-driven water-splitting cycle based on cerium oxides, Sol. Energy. 80 (2006) 1611-1623. doi:http://dx.doi.org/10.1016/j.solener.2005.12.005.

[32] M. Chambon, S. Abanades, G. Flamant, Thermal dissociation of compressed ZnO and $\mathrm{SnO}_{2}$ powders in a moving-front solar thermochemical reactor, AIChE J. 57 (2011) 2264-2273. doi:10.1002/aic.12432.

[33] E. Koepf, W. Villasmil, A. Meier, Pilot-scale solar reactor operation and characterization for fuel production via the $\mathrm{Zn} / \mathrm{ZnO}$ thermochemical cycle, Appl. 
Energy. 165 (2016) 1004-1023. doi:https://doi.org/10.1016/j.apenergy.2015.12.106.

[34] A. Steinfeld, R. Palumbo, Solar thermochemical process technology, Encycl. Phys. Sci. Technol. 15 (2001) 237-256.

[35] M. Tsuji, Y. Wada, Y. Tamaura, A. Steinfeld, P. Kuhn, R. Palumbo, Coal Gasification Using the ZnO/Zn Redox System, Energy \& Fuels. 10 (1996) 225-228. doi:10.1021/ef950121y.

[36] C. Wieckert, A. Steinfeld, Solar Thermal Reduction of $\mathrm{ZnO}$ Using $\mathrm{CH}_{4}: \mathrm{ZnO}$ and C:ZnO Molar Ratios Less Than 1, J. Sol. Energy Eng. 124 (2001) 55-62. http://dx.doi.org/10.1115/1.1434980.

[37] T. Osinga, U. Frommherz, A. Steinfeld, C. Wieckert, Experimental Investigation of the Solar Carbothermic Reduction of ZnO Using a Two-cavity Solar Reactor, J. Sol. Energy Eng. 126 (2004) 633-637. http://dx.doi.org/10.1115/1.1639001.

[38] A. Steinfeld, I. Spiewak, Economic evaluation of the solar thermalco-production of zinc and synthesis gas, Energy Convers. Manag. 39 (1998) 1513-1518. doi:https://doi.org/10.1016/S0196-8904(98)00102-2.

[39] A. Steinfeld, A. Frei, P. Kuhn, D. Wuillemin, Solar thermal production of zinc and syngas via combined $\mathrm{ZnO}$-reduction and $\mathrm{CH}_{4}$-reforming processes, Int. J. Hydrogen Energy. 20 (1995) 793-804. doi:http://dx.doi.org/10.1016/0360-3199(95)00016-7.

[40] K.J. Warren, R.J. Carrillo, B. Greek, C.M. Hill, J.R. Scheffe, Solar Reactor Demonstration of Efficient and Selective Syngas Production via Chemical Looping Dry Reforming of Methane over Ceria, Energy Technol. 8 (2020) 2000053. doi:10.1002/ente.202000053.

[41] K.J. Warren, J.R. Scheffe, Kinetic insights into the reduction of ceria facilitated via the partial oxidation of methane, Mater. Today Energy. 9 (2018) 39-48. doi:https://doi.org/10.1016/j.mtener.2018.05.001. 
[42] A. Steinfeld, C. Larson, R. Palumbo, M. Foley, Thermodynamic analysis of the coproduction of zinc and synthesis gas using solar process heat, Energy. 21 (1996) 205222. doi:http://dx.doi.org/10.1016/0360-5442(95)00125-5.

[43] A. Steinfeld, M. Brack, A. Meier, A. Weidenkaff, D. Wuillemin, A solar chemical reactor for co-production of zinc and synthesis gas, Energy. 23 (1998) 803-814. doi:10.1016/S0360-5442(98)00026-7.

[44] S. Kräupl, A. Steinfeld, Experimental Investigation of a Vortex-Flow Solar Chemical Reactor for the Combined $\mathrm{ZnO}$-Reduction and $\mathrm{CH}_{4}$-Reforming*, J. Sol. Energy Eng. 123 (2001) 237-243. http://dx.doi.org/10.1115/1.1384569.

[45] S. Kräupl, A. Steinfeld, Pulsed Gas Feeding for Stoichiometric Operation of a GasSolid Vortex Flow Solar Chemical Reactor, J. Sol. Energy Eng. 123 (2000) 133-137. http://dx.doi.org/10.1115/1.1351172.

[46] R.R. Bhosale, Thermodynamic efficiency analysis of $\mathrm{ZnO} / \mathrm{Zn}$ based solar thermochemical $\mathrm{CH}_{4}$ reforming and $\mathrm{H}_{2} \mathrm{O}$ splitting cycle, Int. J. Hydrogen Energy. 45 (2020) 5760-5771. doi:https://doi.org/10.1016/j.ijhydene.2019.05.191.

[47] S. Chuayboon, S. Abanades, Combined $\mathrm{ZnO}$ reduction and methane reforming for coproduction of pure $\mathrm{Zn}$ and syngas in a prototype solar thermochemical reactor, Fuel Process. Technol. 211 (2021) 106572.

doi:https://doi.org/10.1016/j.fuproc.2020.106572. 